University of Wollongong

Research Online

Faculty of Business - Papers (Archive)

Faculty of Business and Law

$1-1-2016$

Family control, accounting misstatements, and market reactions to restatements: evidence from China

\author{
Liangbo Ma \\ University of Wollongong, liangbo@uow.edu.au \\ Shiguang $\mathrm{Ma}$ \\ University of Wollongong, shiguang@uow.edu.au
}

Gary G. Tian

Macquarie University, gtian@uow.edu.au

Follow this and additional works at: https://ro.uow.edu.au/buspapers

Part of the Business Commons

Research Online is the open access institutional repository for the University of Wollongong. For further information contact the UOW Library: research-pubs@uow.edu.au 


\title{
Family control, accounting misstatements, and market reactions to restatements: evidence from China
}

\author{
Abstract \\ We examine the impact of family control on the likelihood of accounting misstatements and on market \\ reactions to subsequent restatements. Using a matched-firm approach, we find that family control overall \\ reduces the incidence of misstatements, consistent with the notion that controlling families have a \\ greater concern for reputation than nonfamily blockholders. However, compared to nonfamily firm \\ restatements, restatements announced by family-controlled firms trigger significantly more negative \\ market reactions. We attribute the more negative market reactions to the greater loss in reputation and \\ higher investor scepticism of the credibility of corporate insiders for family firms than for nonfamily firms \\ following restatements.

\section{Disciplines \\ Business}

\section{Publication Details} \\ Ma, L., Ma, S. \& Tian, G. G. (2016). Family control, accounting misstatements, and market reactions to \\ restatements: evidence from China. Emerging Markets Review, 28 1-27.
}


Family Control, Accounting Misstatements, and

\title{
Market Reactions to Restatements: Evidence from China
}

\author{
LIANGBO MA*, SHIGUANG MA, GARY TIAN
}

School of Accounting, Economics, and Finance,

University of Wollongong, Australia

\begin{abstract}
We would like to thank Jonathan A. Batten (the Editor) and Duc Khuong Nguyen (subject editor) for their support. We also thank two anonymous reviewers and participants at the $27^{\text {th }}$ Australasian Finance \& Banking Conference (Sydney, December 2014) for their helpful comments. All errors remain ours.

* Corresponding author. Northfields Avenue, Wollongong, New South Wales 2522, Australia;

E-mail: liangbo@uow.edu.au; Tel: +61 24221 3312; Fax: +61 242214297.
\end{abstract}




\title{
Family Control, Accounting Misstatements, and Market Reactions to Restatements: Evidence from China
}

\begin{abstract}
:
We examine the impact of family control on the likelihood of accounting misstatements and on market reactions to subsequent restatements. Using a matched-firm approach, we find that family control overall reduces the incidence of misstatements, consistent with the notion that controlling families have a greater concern for reputation than nonfamily blockholders. However, compared to nonfamily firm restatements, restatements announced by familycontrolled firms trigger significantly more negative market reactions. We attribute the more negative market reactions to the greater loss in reputation and higher investor scepticism of the credibility of corporate insiders for family firms than for nonfamily firms following restatements.
\end{abstract}

Keywords: Family firm; Restatement; Financial reporting; Market reaction.

JEL classification: D8; G14; G32; M41 


\section{Introduction}

High-quality accounting information plays a central role in designing the mechanisms that mitigate various agency conflicts among blockholders, managers, and outside investors (Bushman \& Smith, 2001; Healy \& Palepu, 2001; Armstrong, Guay, \& Weber, 2010). Because of the prevalence of family firms across the globe, a growing number of studies examine the association between family ownership/control and the quality of accounting information (e.g., Wang, 2006; Chen, Chen, \& Cheng, 2008; Cascino, Pugliese, Mussolino, \& Sansone, 2010; Chen, Chen, \& Cheng, 2014). The evidence from existing studies is, however, inconclusive. Moreover, little is known about whether and how family control influences the way investors react to changes in accounting information quality.

In this study we build on prior literature to examine the impact of family control on accounting restatements. ${ }^{1}$ Specifically, we aim to answer two related questions. Does family control reduce or increase the likelihood of a firm misstating its accounting statement? Do investors react differently to restatements announced by family-controlled firms and those by nonfamily-controlled firms? ${ }^{2}$ We focus on accounting restatements not only because the unprecedented number of accounting restatements have caused great concern among regulators and other market participants, but also because restatement is one of the most visible forms of low-quality accounting information (Cao, Myers, \& Omer, 2012) and there is

\footnotetext{
${ }^{1}$ Throughout this paper, we use the term 'family firms (nonfamily firms)' or 'family-controlled firms (nonfamilycontrolled firms)' interchangeably, because our definition of family firms requires that the founding family exercises effective control of the firm (see Section 3.3.1 for more details).

${ }^{2}$ Because prior literature finds significant differences in market reactions between restatements of a material and immaterial nature and between restatements initiated by different parties (e.g, Palmrose, Richard, \& Scholz, 2004; Hennes et al., 2008; Firth, Rui, \& Wu, 2011; Cao et al., 2012), in this paper we focus on mandatory material restatements to avoid unnecessary complexity. However, future research to further examine the possible different impacts of family control on these different types of restatements will be interesting.
} 
no need for researchers to use a model to identify low-quality firms (Dechow, Ge, \& Schrand, 2010).

The link between family control and the likelihood of accounting restatements is well supported by economic theory and existing literature. The multi-generation nature of controlling families' ownership suggests that they have greater concern for reputation than nonfamily blockholders (Gilson, 2007; Chen et al., 2008). This will deter family-controlled firms from misstating their financial statements not only because subsequent restatements often cause substantial reputational penalties (Karpoff, Lee, \& Martin, 2008; Murphy, Shrieves, \& Tibbs, 2009), but also because family owners may lose certain other nonpecuniary benefits, such as high social status and political connections, which are reputation-based. In addition, restatements are often associated with a wide range of negative consequences (e.g., Palmrose, Richardson, \& Scholz, 2004; Hribar \& Jenkins, 2004; Graham, Li, \& Qiu, 2008; Firth, Rui, \& Wu, 2011). Family owners' concentrated and underdiversified equity ownership means that they will bear a significant proportion of economic losses resulting from mandatory restatements, which further reduces family owners' incentive for misreporting.

In summary, controlling families' greater concern for reputation, high equity ownership, and their dominant positions and better monitoring of managers, indicate that they have more incentives, as well as the capacity, to provide high-quality accounting information, leading to a negative relationship between family control and the likelihood of misstatements.

We next explore whether investor reactions to subsequent restatements differ between family-controlled firms and nonfamily-controlled firms. Family-controlled firms are characterized by potentially more severe agency conflicts between the controlling shareholder and minority shareholders, suggesting that investors have a greater demand for high-quality accounting information for family-controlled firms and consequently are more sensitive to 
the deterioration in the quality of accounting information in family-controlled firms than in nonfamily-controlled firms. Restatements provide new information that leads outside investors not only to lower their expectation about the quality of accounting information, but also to increase their concerns about management's opportunistic decision making, with both effects likely to have more negative consequences for family firms than for nonfamily firms. Therefore, investors are likely to react more negatively to restatements announced by familycontrolled firms than to those by nonfamily-controlled firms.

In addition, accounting restatements reveal that the design and / or the implementation of corporate governance is relatively weak, deepening investors' concerns about possible expropriation by controlling shareholders, which is perceived to be more severe in familycontrolled firms than in nonfamily-controlled firms. Finally, the literature finds that the media is more likely to publicize targets or events about which there is a higher demand for information or with high prominence (e.g., Fombrun \& Shanley, 1990; Dyck \& Zingales, 2003). This suggests that restatements announced by family-controlled firms are likely to attract more media attention, which further enhances the more negative market reactions to family firm restatement announcements. Combining the above analysis, we predict that investors' greater concerns about controlling families' opportunistic behaviour and the unfavourable media coverage are likely to trigger more negative market reactions to restatements announced by family-controlled firms than those announced by nonfamilycontrolled firms.

We test our hypotheses using a sample of 151 accounting restatements announced by Chinese public firms in the period 2004 to 2010. The majority of the restatement literature focuses on the US market. The US has one of the most widely dispersed ownership structures and most favourable institutional environments, which suggests that both the causes and the consequences of accounting restatements are likely to differ significantly between the US and 
many other countries (Coffee, 2005). China is characterized by a weak legal environment, underdeveloped but fast-growing financial markets, and a highly concentrated ownership structure, making China a good representative of many emerging markets. Another salient feature and advantage of Chinese data is that the vast majority of listed firms in China have a dominant controlling shareholder with a high ownership stake. This allows us to implicitly control for ownership concentration, giving us greater confidence to conclude that our findings are truly attributable to the nature of family control rather than to ownership concentration itself.

Using a matched-firm approach, we find that, compared to nonfamily-controlled firms, family-controlled firms in China are significantly less likely to misstate their annual financial statements, even after controlling for firm characteristics and other corporate governance proxies that are found to be associated with accounting misstatements in prior studies. This finding is consistent with the notion that controlling families have a greater concern for reputation as well as the overall evidence that family owners have greater incentives to mitigate agency costs than nonfamily blockholders (e.g., Wang, 2006; Chen et al., 2008; Chen et al., 2014).

With respect to investor reactions to accounting restatements, we find that family control is associated with significantly stronger market reactions, specifically more negative cumulative abnormal return (CAR), higher abnormal return variance (ARV), higher abnormal trading volume (ATV), and higher abnormal bid-ask spread (ABAS), over short windows surrounding the restatement announcement. The stronger negative reactions to family firm restatements are even more pronounced when the risk of expropriation by the controlling shareholder is higher. We also find that family restatement firms experience a significantly larger loss in the information content of earnings measured by the earnings response coefficient (ERC) compared to nonfamily restatement firms. 
This paper contributes to the literature in several ways. First, we establish a direct link between family control and market reactions to accounting restatements. In this regard, our study complements an important body of literature that tries to identify the determinants of market reactions to restatements. For example, more negative stock returns are found to be associated with restatements that involve frauds (Palmrose et al., 2004), core accounts (Palmrose \& Scholz, 2004; Agrawal \& Chadha, 2005), less accounting complexity (Peterson, 2012), and restatements that reduce earnings (Palmrose et al., 2004; Callen, Robb, \& Segal, 2008). This study generates direct evidence that the identity of controlling shareholders, in this case founding families, can also influence market reactions to accounting restatements. Specifically, our results show that investors are more sensitive to the deterioration in accounting information quality, as proxied by accounting restatements, in family-controlled firms than in nonfamily-controlled firms; consequently they react more negatively to family firm restatements than to nonfamily firm restatements. Existing evidence on the impact of family control on market reactions to restatements is scarce.

Second, the existing literature on family firms commonly relies on the assumption that family firms have a greater concern for reputation than nonfamily firms because, compared to nonfamily blockholders, family owners usually have a longer investment horizon, a greater equity ownership, a larger proportion of their wealth tied to the success of the firms, and greater nonpecuniary benefits. However, there is little direct empirical evidence that family control leads to greater corporate reputation. We build on prior literature to address an important but largely ignored question, 'What are the implications or consequences when the reputation of controlling families is impaired?' The stronger and more negative reactions and the larger drop in ERC following accounting restatements by family firms indicate more severe consequences once investors' higher expectations about family firms' concern for 
reputation is violated. Our results thus provide indirect empirical evidence that family firms do have greater incentives to build and maintain a good reputation.

To some extent, our findings are consistent with those in Kouwenberg and Phunnarungsi (2013), who find larger negative market reaction to announcements of violations of rules and regulations when firms with low past violation records (i.e., good reputation) violate the rules. In this regard, our study also provides empirical support to the expectancy violation theory (Burgoon \& LePoire, 1993; Rhee \& Haunschild, 2006).

Third, this study enhances our understanding of the impact of family control/ownership on accounting information quality, especially for emerging markets. Fan and Wong (2002) find that concentrated ownership in East Asia is associated with less informative earnings. Our study in contrast suggests a negative relationship between family control and the likelihood of accounting misstatements (i.e., higher earnings quality). We offer two possible explanations for the seemingly contradictory results. First, Fan and Wong (2002) examine the impact of ownership concentration, while we focus on the impact of family control. As we argue throughout this paper, the incentives and the impact of controlling families are different from those of nonfamily blockholders. The unique feature of Chinese data allows us to attribute our findings to the nature of family control rather than to ownership concentration itself. Second, for firms listed in the Chinese markets where a large number of firms have relatively low-quality information, providing low-quality earnings (e.g., large discretionary accruals or less timely loss recognition) does not necessarily impair a firm's (and ultimately the controlling shareholder's) reputation. In contrast, accounting misstatements and subsequent restatements are much more serious than other forms of low-quality information and therefore are more likely a reputation-impairing event. The analysis and our empirical evidence thus suggest that a positive association between family ownership/control and information opacity (or other forms of low-quality accounting information) do not necessarily 
imply a positive association between family ownership/control and the likelihood of accounting misstatements.

We note that the relationship between family firms and accounting restatements has been addressed by several papers, such as Agrawal and Chadha (2005) and Tong (2007), both using US data. While Agrawal and Chadha (2005) find that a firm is more likely to restate its earnings if the CEO belongs to the founding family, Tong (2007) finds a lower probability of restatements among family firms than nonfamily firms. Apart from using Chinese data instead of US data, our paper differs from these two papers in one important aspect. Neither Agrawal and Chadha (2005) nor Tong (2007) distinguish between voluntary restatements and mandatory (or forced) restatements. As Srinivasan, Wahid, and Yu (2015) point out, a lower rate of voluntary restatements could possibly indicate a lack of detection and disclosure of accounting errors and irregularities and thus a lower earnings quality. The exclusion of voluntary restatements from our study gives us relatively high confidence to conclude that the lower incidence of mandatory restatements among family firms does suggest that family firms have a higher reporting quality than nonfamily firms.

The rest of this paper proceeds as follows. Section 2 reviews related literature and presents our hypotheses. Section 3 describes our research design and sample. Section 4 reports our main empirical results. Section 5 carries out some robustness tests. Finally, Section 6 concludes.

\section{Literature Review and Hypothesis Development}

\subsection{Family Control and Accounting Misstatements}

Direct evidence on the relationship between family control and the incidence of accounting misstatement is scarce. Therefore, we briefly review the literature that elaborates the unique characteristics of family ownership and some empirical evidence on the 
relationship between family firms and the quality of accounting information, from which we then introduce our hypotheses.

The literature often points out family owners' greater concern for reputation as a salient characteristic of family firms. Gilson (2007) points out that 'because of intrafamily inheritance and family ties, the current generation of decision makers, at least in functional family businesses, treats the next generation's utility as the equivalent of their own' (p. 643). Therefore, family owners' desire to pass on successful family businesses to future generations can constitute a powerful motivation to adopt a long-term investment approach and naturally give them greater incentives to invest more to build and protect a reputation (Gilson, 2007; Miller, Le Breton-Miller, \& Scholnick, 2008). In addition, Burkart, Panunzi, and Shleifer (2003) point out that a family name connected to a successful family business may bring in nonpecuniary or reputational benefits, such as a high social status and political connections. The analysis thus suggests that controlling families have stronger incentives than nonfamily blockholders not to misstate their financial statements, because misstatements could impair or even damage a firm's reputation, which is more difficult to restore for family firms than for nonfamily firms.

We argue that family owners in China are likely to have an even greater concern for reputation than their counterparts in more developed markets. The relatively weak formal institutions in China, and especially the lack of an effective judicial and investor protection system, mean outside investors have few channels through which to take action against controlling shareholders when their rights are jeopardized (MacNeil, 2002; Allen, Qian, \& Qian, 2005). As a result, contracting and financing in China often rely on alternative informal governance mechanisms. Reputation probably plays the most important role in informal enforcement, along with relationship (Allen et al., 2005; Gilson, 2007; Fan, Wong, \& Zhang, 
2012). This is in stark contrast with contracting in more developed markets where it is largely based on rule of law.

Controlling families' long-term oriented approach also means they are less interested in the day-to-day stock price movements, thus giving family-controlled firms less incentive to manage earnings to manipulate short-term stock prices. In addition, the (frequent) unification of the positions of controlling shareholder and management, or their dominant power over nonfamily managers, suggests that controlling families are effective 'monitors-in-place' (Anderson, Duru, \& Reeb, 2009) who are both motivated and well positioned to discipline managerial agents. Furthermore, family members are often as knowledgeable as managers about their firms, enabling them to provide effective checks on professional managers. Consistent with this view, Chen (2005) finds that not only can family owners quickly detect managers' manipulation of accounting information, they can also rely less on accountingbased performance measures in designing management compensation. This in turn reduces managers' opportunistic behaviour in earnings management (Jensen \& Meckling, 1976; Coffee, 2005).

To provide further support to our argument, it is worth pointing out some of the salient characteristics that differentiate a typical nonfamily firm from a family firm in China. Unlike in the US and UK where most firms are widely held, the majority of non-SOEs in China have at least one blockholder with more than $10 \%$ of cash flow rights (Ma, Ma, \& Tian, 2015). In fact, the largest blockholder holds an average of $32.6 \%$ of all control rights, which is above the $30 \%$ threshold set by the CSRC in determining effective control (Ma, Ma, \& Tian, 2013). Such a concentrated ownership structure gives the controlling shareholder great power in influencing corporate behaviour. Compared to family owners, nonfamily blockholders usually have a shorter investment horizon and are less concerned about reputation. As a result, 
nonfamily firms are more likely to expropriate minority shareholders and provide less transparent information to conceal their expropriation (Ma, Ma, \& Tian, 2013, 2015).

Taken together, controlling families' greater concern for reputation and the long-term nature of their equity holding motivate them to provide high-quality accounting information. Thus, we present our first hypothesis as follows:

H1: Compared to nonfamily-controlled firms, family-controlled firms are less likely to misstate their accounting statements.

\subsection{Family Control and Market Reactions to Accounting Restatements}

Family firms are also characterized by concentrated ownership that may possibly imply more severe agency problems between large shareholders and minority shareholders. Minority shareholders, being concerned about the potential risk of expropriation by controlling families, will demand high-quality accounting information. This suggests that, compared to minority shareholders in nonfamily-controlled firms, those in family-controlled firms are more sensitive to the quality and hence the deterioration in the quality of accounting information. In addition, a strong internal corporate governance system is important in helping to mitigate agency conflicts, especially when external governance (e.g., statutory regulation and formal institutions) is weak, such as in the Chinese market. Restatements provide new information that allows outside investors to learn that either the firm's internal governance policy is not well designed to prevent controlling shareholders' opportunistic behaviour, or such a governance system is not effectively implemented (Kinney \& McDaniel, 1989). Furthermore, restatements exacerbate the information asymmetry between insiders and minority shareholders, making it even more difficult for minority shareholders to assess the efficacy of a firm's internal governance. As minority shareholders are generally more concerned about controlling shareholders' opportunistic behaviour in family-controlled firms 
than in nonfamily-controlled firms, the analysis above thus suggests more negative investor reactions to restatements announced by family-controlled firms.

In addition, a number of studies find that the media (or the press) can play an important role in identifying and monitoring firm frauds (Miller, 2006). In choosing which firm or fraud to cover, reporters/publishers will maximize the benefits of articles by focusing on firms that have high visibility or those where there is a great demand for information (Dyck \& Zingales, 2003). The literature finds that the media is more likely to publicize targets or events involving firms / people who are prominent or of high reputation (Fombrun \& Shanley, 1990; Hoffman \& Ocasio, 2001). This suggests that, compared to nonfamily firm restatements, restatements by family-controlled firms, and in particular those involving high-profile entrepreneurs, are more attractive to readers and more likely to be picked up by the media. Does such a bias in media coverage affect investor reactions? Dyck and Zingales (2003) find that stock prices are most reactive to earnings announcements emphasized by the media, which implies that investors will react more strongly to family firm restatements than to nonfamily firm restatements, because the former are likely to attract more intense media coverage.

Finally, firms found to be involved in accounting irregularities and other frauds commonly take action in a bid to improve corporate governance and to restore investor trust. Replacing the CEO and/or other members of the firm's top management is one of the most typical actions (Hennes, Leone, \& Miller, 2008; Karpoff et al., 2008). It is a common practice for the founder or other members from the controlling family to take key management positions in family firms. The literature has provided theoretical (e.g., Schulze, Lubatkin, \& Dino, 2003) and empirical evidence (e.g., Leone \& Liu, 2010) that a top manager from the controlling family is significantly less likely than an outside manager to be punished or even fired, especially when such an action will have a spillover effect on family relationships 
outside the business. The discussion here thus suggests that, compared to nonfamily firms, family firms are often short of one important and effective tool to signal to investors their intent and commitment to improve corporate governance and to restore investor trust.

Summing up our discussion, on the one hand, minority investors have a higher expectation that controlling families will be concerned about their reputation ; while, on the other hand, they have greater concerns about controlling families' opportunistic behavior. Thus, they have both a higher expectation about the supply of, and a greater demand for, high-quality accounting information from family-controlled firms. Once a family-controlled firm restates its accounting statement, minority investors' initial expectation about reputation is violated and their concerns about controlling families' opportunistic behaviour become dominant. In other words, a restatement by a family firm will turn around investors' attitude towards them. Such a perception, together with the unfavourable bias in media coverage, is likely to lead minority investors to react more negatively to family firm restatements. Thus, we state our second hypothesis as follows:

H2: Accounting restatements announced by family-controlled firms lead to stronger and more negative market reactions than restatements announced by nonfamily-controlled firms.

\subsection{Expropriation risk and the impact of family control on market reactions}

The above analysis suggests that, after the restatement announcement, investors reassess their expectation and perception about the controlling families' commitments and behaviour. Specifically, a restatement is likely to lower the credibility of the accounting information in the restatement firm and increase outside investors' mistrust of the controlling families/managers, as well as their concerns about controlling families' opportunistic and expropriating behaviour. Naturally the increase in investors' concern will be more significant in an environment where such a risk of expropriation is perceived to be higher, for example, when the controlling shareholders' control-ownership wedge is higher and when corporate 
information is more opaque (Shleifer \& Vishny, 1997; Claessens, Djankov, Fan, \& Lang, 2002; Leuz, Nanda, \& Wysocki, 2003; Anderson et al., 2009). Consequently, the more negative market reactions to family firm restatements will be even more significant. Thus, we state our third hypothesis as follows:

H3: The impact of family control on market reactions to restatements is more pronounced when the risk of expropriation by the controlling family is higher.

\section{Research Design and Sample}

\subsection{Research Design}

To test our first hypothesis $H 1$, we estimate the following logit model:

$$
\text { Misstate }=\beta_{0}+\beta_{1} \text { Family }^{k} \sum_{2}^{k} \beta_{i} \text { Control }_{i}+\text { Fixed Effects }+\varepsilon
$$

In this model, Misstate is a dummy variable that equals 1 if a firm misstates its annual financial report in a given period; Family is a dummy variable that denotes a familycontrolled firm; and Control $_{i}$ is a set of control variables. All control variables in Eq. (1) are measured in the year when the misstatement occurs and not in the year when a subsequent restatement is announced. $H 1$ predicts $\beta_{1}$ to be negative as we expect family control will lower the likelihood of a firm misstating its financial report.

To test our second hypothesis $H 2$, we estimate the following baseline regression model:

$$
\text { Market Reaction }_{i}=\beta_{0}+\beta_{1} \text { Family }+\sum_{2}^{k} \beta_{i} \text { Control }_{i}+\text { Fixed Effects }+\varepsilon_{i}
$$

In this model, Market Reaction is the reaction generated by a firm's announcement of an accounting restatement and is represented by one of the following four measures: cumulative abnormal return (CAR), abnormal return variance (ARV), abnormal trading volume (ATV), or abnormal bid-ask spread (ABAS) over the short-term window surrounding the announcement. According to $H 2$, family control leads to stronger and more negative market 
reactions to a restatement announcement. Thus, we expect $\beta_{1}$ to be negative when market reaction is measured by CAR and $\beta_{1}$ to be positive when market reaction is represented by the other three measures. While it is relatively easy and straightforward to understand an expected positive $\beta_{1}$ when market reaction is measured by ARV and ABAS, the reason why family control is positively associated with ATV is as follows. Karpoff (1987) argues that volume is positively related to the magnitude of price change and to the price change per se. Friedman (1969) further points out that a heavy volume of trading reflects differences of opinion among investors about the future course of prices. We argue that restatements by family firms result in even greater uncertainty about the credibility of the firms' postrestatement performance, as well as the performance per se, which should be reflected in larger short-term stock return variances, which in turn are expected to be associated with larger trading volumes based on the theoretical and empirical evidence in Karpoff (1987) and Friedman (1969).

In addition to the baseline regression model, we will also examine whether the relationship between family control and market reactions is affected by the risk of expropriation by the controlling shareholder $(H 3)$. To test our proposition, we estimate the following regression model:

$$
\begin{aligned}
\text { Market Re action }_{i} & =\beta_{0}+\beta_{1} \text { Family } \\
& +\beta_{2} \text { Family } * \text { Ownership Wedge (or Corporate Opacity) } \\
& +\beta_{3} \text { Ownership Wedge (or Corporate Opacity) } \\
& +\sum_{4}^{k} \beta_{i} \text { Control }+ \text { Fixed Effects }+\varepsilon_{i}
\end{aligned}
$$

In this model, Ownership Wedge is the difference between the controlling shareholder's control (voting) rights and cash flow rights; Corporate Opacity, measured by a comprehensive index that consists of four components based on stock trading information and analyst coverage, gauges the relative information opaqueness of a firm. We predict that 
the relationship between family control and market reactions will strengthen as the potential expropriation risk rises. Thus, the coefficients $\beta_{2}$ in Eq. (3) are expected to have the same signs as that of $\beta_{1}$ in Eq. (2).

We estimate all regressions by controlling for year and industry fixed effects. Industry dummies are based on the two-digit classification issued by the China Securities Regulatory Commission (CSRC). All continuous variables are winsorized at the $1 \%$ and $99 \%$ levels to minimize the influence of outliers. In line with prior studies, we control for heteroscedasticity using White-adjusted standard errors.

\subsection{Sample Construction}

Since 1993 regulators in China have issued a series of laws and regulations in relation to information disclosure by publicly listed firms. However, it was not until 2004 that regulators explicitly set the requirement that a listed firm 'must in a timely manner disclose restated financial information in the format of a significant event announcement, if there are accounting errors' ${ }^{3}$ Thus, restatements of substantive significance exist only after 2004.

There are three broad types of announcements of financial information restatements in the Chinese markets: appending ('bu chong' in Chinese pinyin), correcting ('geng zheng' in pinyin), and supplement to correcting ('bu chong geng zheng' in pinyin). Appending announcements, which account for about one half of all restatements (Lei, $\mathrm{Wu}, \mathrm{Wu}$, \& Rui, 2006), mainly concern ownership, directors, or other corporate governance-related nonfinancial information. Appending announcements usually have no or little impact on the valuation of the announcing firms and thus are excluded from this study. Correcting and supplement to correcting announcements, in contrast, often contain important financial

\footnotetext{
3 'Notice of further improving the quality of financial information disclosure by listed companies', CSRC, January 6, 2004.
} 
information that has a significant impact on firm valuation. Typically, a correcting or supplement to correcting announcement concerns one or more of the following items: misinterpreting relevant rules or regulations, recognition of revenues or expenses, asset transactions, investments, related party transactions, and pending litigations.

A restatement can be either internally initiated by the firm's management (i.e., a voluntary restatement) or externally initiated by either its auditor or regulators, such as the stock exchange or CSRC (i.e., a mandatory restatement). Srinivasan, Wahid, and Yu (2015) argue that a lower rate of voluntary restatements could probably indicate a lower, rather than a higher, reporting quality. Therefore, we exclude all voluntary restatements from this study.

Our sample selection procedures are as follows. We first manually check all announcements containing the keyword 'correction' ('geng zheng' in Chinese pinyin) that are issued by listed nonfinancial firms on the Shenzhen and Shanghai Stock Exchange websites. Our sample period spans the years 2004 to 2010. Although our study focuses on misstatements and restatements of annual reports only ${ }^{4}$, we do not include 'annual' or 'annual report' in our filtering keywords because we note that a number of restatement announcements do not contain these two words. In other words, including 'annual' or 'annual report' in our search would significantly reduce our sample size.

We first exclude 'ST' (special treatment) firms. ST firms are those firms that have made losses in two consecutive years and face the risk of being delisted if they continue to make losses for a third year, which gives them a strong incentive to misreport their financial statements. The trading behaviour of ST firms is also likely to be different from other non-ST firms. We then restrict our sample to non-state-owned enterprises (non-SOEs) for the

\footnotetext{
${ }^{4}$ Listed firms in China are not mandatorily required to have their quarterly and half-yearly financial statements formally audited. Thus, these two types of financial statements are not expected to have the same credibility as annual statements.
} 
following reasons. SOEs in China often have various political and social objectives, such as improving employment, strengthening fiscal conditions of local governments, and maintaining social stability, in addition to operating performance. Therefore, compensation and/or promotion of managers of SOEs rely less on accounting measures when compared to managers of non-SOEs. Moreover, SOEs' access to bank loans is also less related to firm performance. Thus, compared to managers of non-SOEs, managers of SOEs have weaker incentives to manipulate accounting earnings. Furthermore, Firth et al. (2011) point out that even when false accounting has occurred, disclosure of it through accounting restatements is less likely for SOEs than for non-SOEs. We require that a firm is a non-SOE both in the year of misstatement and in the year of restatement. We identify 420 restatements announced by non-SOEs during our sample period.

Following Firth et al. (2011), we next limit our sample to restatements that affect revenues, net earnings, or/and assets. We also exclude restatements resulting from minor or technical errors (e.g., nondisclosure of immaterial information, misprints, or simple miscalculations in the original annual reports), because Hennes et al. (2008) emphasize the importance of distinguishing between errors and irregularities. These criteria reduce the sample size to $183 .{ }^{5}$ Next, we exclude restatements that are corrections or supplementary restatements to previously announced restatements. This requirement further reduces our sample size to 177 . Finally, we eliminate observations that lack the required stock trading data. As a result, our selection criteria yield a final sample of 151 restatements. Our sample construction procedure is summarized in Table 1.

Consistent with prior studies (e.g., Agrawal \& Chadha, 2005; Leone \& Liu, 2010; Firth et al., 2011; Kryzanowski \& Zhang, 2013), we adopt a matched-firm approach. We match each of our 151 restatement firms with a matching firm that satisfies all of the following criteria:

\footnotetext{
${ }^{5}$ Please refer to Appendix B for examples of accounting errors and irregularities.
} 


\section{Table 1 Sample selection}

This table summarizes our sample selection process. The sample period is between 2004 and 2010 . Each restatement firm is matched with a control firm that is based on size, IPO year, stock exchange, and CSRC two-digit industry code. Each control firm is required to have not announced a restatement within a five-year window.

\begin{tabular}{|lc|}
\hline Number of restatements of annual reports identified on the Shenzhen and \\
Shanghai Stock Exchange websites & 492 \\
(requiring that a firm is a non-SOE in the year the restatement is announced) & \\
$\quad$ Less restatements where the firm is an SOE in the year of misstatement & $(72)$ \\
All restatements issued by non-state-controlled firms & 420 \\
$\quad$ Less restatements that result from minor and/or technical errors & $(237)$ \\
Restatements that involve corrections to revenue, earnings, or assets & 183 \\
$\quad$ Less restatements that are a correction or supplementary to previous & $(6)$ \\
restatements & $(26)$ \\
$\quad$ Less restatements that lack required stock trading data & $\mathbf{1 5 1}$ \\
Sample of restatements & 151 \\
Plus matching firms & $\mathbf{3 0 2}$ \\
Total sample of restatement and matching firms & \\
\hline
\end{tabular}

(1) has the same CSRC two-digit industry code as the restatement firm; (2) is a non-SOE both in the year of misstatement and in the year of restatement; (3) has the closest size (total assets) to the restatement firm; (4) does not announce any material restatements within a five-year window (two years before and two years after) surrounding the announcement of a restatement by the restatement firm; (5) has been listed for the same number of years (and on the same stock exchange when possible) as the restatement firm; and (6) is not an ST firm. The average misstatement firm is slightly smaller than the average matching firm $(p=0.093)$. We control for firm size in all multivariate regressions.

We obtain our accounting, ownership, and other corporate governance data from the China Securities Market and Accounting Research (CSMAR) database. Compiled by Shenzhen GTA Information Technology Company Ltd., CSMAR is one of the most widely used databases for research on the Chinese stock market. Daily stock return and trading volume data are also from CSMAR; while data used to calculate bid-ask spreads is provided by Securities Industry Research Centre of Australia (SIRCA). 


\subsection{Variable Definitions}

\subsubsection{Family control}

Because of concentrated ownership in many European and East Asian countries, researchers commonly apply a minimum threshold for the largest shareholder's ownership to ensure effective control (Fan \& Wong, 2002; Dyck \& Zingales, 2004). In this study, we use a dummy variable Family to denote family control if: (1) the founder and members of the founding family (either by blood or through marriage) hold at least $20 \%$ of the firm's control rights; and (2) the founding family (all family members combined) is the ultimate largest shareholder.

In addition to the criteria described above we also apply some other rules in determining a family-controlled firm, given the unique characteristics of the Chinese markets. First, if a firm is established by more than one family, we regard the family with the largest control rights as the controlling family. Second, private individuals were not allowed to own or control a business until some years after the start of the economic reform; until then many businesses were registered as village and town enterprises (VTEs), even though they were founded and controlled by natural persons. There firms were later re-registered as private enterprises when this was permitted by the new laws. In those cases these firms are regarded as family firms if they meet the two criteria of our family firm definition (i.e., ultimate largest shareholder with at least $20 \%$ control rights). In some other cases, managers of VTEs later become the controlling shareholders through management buyouts. We view these firms as nonfamily firms, even if the controlling shareholders have more than $20 \%$ of control rights.

\subsubsection{Market reactions}

In this paper, we test market reactions to restatement announcements with four measures, namely cumulative abnormal returns (CAR), abnormal return variance (ARV), abnormal 
trading volume (ATV), and abnormal bid-ask spread (ABAS), over the event window surrounding the announcement.

We follow prior studies such as Firth et al. (2011) and Pevzner, Xie, and Xin (2015) to calculate CAR using the market-adjusted-model returns. We first calculate the daily abnormal return (AR) over the event window from the following model:

$$
A R_{i, t}=R_{i, t}-\left(\alpha_{i}+\beta_{i} * R_{m t}\right)
$$

where $A R_{i, t}$ is the AR of firm $i$ on day $t, R_{i, t}$ is the actual stock return (dividend adjusted) of firm $i$ on day $t, R_{m t}$ is the market return (dividend adjusted) on day $t$, and $\alpha_{i}$ and $\beta_{i}$ are the market model estimates of firm $i$ obtained from the estimation window [-120, -21]. We then sum $A R_{i, t}$ to calculate the CAR over the event window.

We adopt the approach in DeFond, Hung, and Trezevant (2007) and Pevzner et al. (2015) to calculate the ARV as follows. We obtain the stock return variance over the event window as the average of the squared market-adjusted return $A R_{i, t}^{2}$. We next obtain the stock return variance over the estimation window $[-120,-21]$ as the variance of the residual returns from each firm's market model estimated over the estimation window. The ARV is then calculated as the ratio of the stock return variance over the event window to the stock return variance over the estimation window.

We again follow DeFond et al. (2007) and Pevzner et al. (2015) to calculate the ATV by dividing the average daily trading volume over the event window by the average daily trading volume over the estimation window [-120, -21], where trading volume is measured as the number of shares traded on day $t$ scaled by the total number of tradable shares outstanding on day $t$.

We measure the ABAS as the average bid-ask spread over the event window divided by the average bid-ask spread over the estimation window [-120, -21]. Following prior studies such as Cai (2004) and Firth et al. (2011), we use the relative bid-ask spread, i.e., absolute 
spread divided by the average of bid and ask, in our tests. The average relative spread is then calculated as the mean relative spread measured in hourly intervals over the event window and the estimation window, respectively.

\subsubsection{Expropriation risk}

To test $H 3$, we use two variables that are commonly used in the literature as proxies for controlling shareholders' expropriation risk. They are the divergence between controlling shareholder's control and cash flow rights (Ownership wedge) (e.g., Shleifer \& Vishny, 1997; Claessens et al., 2002) and the opacity of a firm's information disclosure (Corporate opacity) (e.g., Leuz et al., 2003; Anderson et al., 2009).

Following prior studies, the control-ownership wedge is calculated as the difference between control rights and cash flow rights of the ultimate largest shareholder. A larger wedge indicates higher risk of expropriation by the controlling shareholder.

To construct the corporate opacity index, we first calculate the four individual components of opacity, namely trading volume, log of the number of analysts following the firm, proportion of zero-return trading days, and daily stock return volatility. We next rank each of these four components into deciles, with a value of 10 representing the most opaque firms and a value of 1 representing the least opaque firms. We then sum these four components and divide it by a factor of 40 , which is the maximum possible value. This process yields a corporate opacity index that ranges from 0.1 to 1 , with higher values indicating greater information opacity and higher expropriation risk.

\subsubsection{Control variables}

We include a set of control variables in our regression models, following prior studies. Firm size (Firm size), profitability (ROA), financial leverage (Leverage), and whether the 
firm records a loss in the previous year (Negative EPS) are found to be associated with the occurrence of accounting restatements in a large number of studies (e.g., Kinney \& McDaniel, 1989; DeFond \& Jiambalvo, 1991; Cao et al., 2012). Starting from 2005, China has conducted a nontradable share (NTS) reform. After the NTS reform, those previous nontradable shares (often held by blockholders) become freely tradable in the stock market. This may have two opposite effects on the likelihood of misstatements. On the one hand, blockholders may become more concerned about potential negative market reactions once misstatements are caught. One the other hand, blockholders may have a greater incentive to misstate financial statements in order to manipulate stock prices. It's unclear which motivation will dominate. Thus, we introduce a dummy variable Reform, which equals 1 if a firm has completed the NTS reform and zero otherwise.

We also control for several corporate governance variables in our regressions. A large number of studies find a positive association between a firm's earnings quality and the external auditor being Big N, both in the international setting (DeFond \& Jiambalvo, 1991; Teoh \& Wong, 1993; Faber, 2005) and for the Chinese market (Chen, Chen, Lobo, \& Wang, 2011; Firth et al., 2011). We therefore control for external auditor identity (Big auditor) and whether a firm receives a modified (nonstandard) opinion on its annual report (MAO) (Kinney \& McDaniel, 1989; Chen, Cumming, Hou, \& Lee, 2013). Big auditor is coded 1 if a firm hires one of the international Big Four auditors, or the six largest national auditors by revenue, to audit its financial reports. ${ }^{6}$ Board independence or the ratio of outside directors (Outside directors) is a commonly used variable in evaluating the strength of corporate governance and has been found to be associated with a lower probability of financial

\footnotetext{
${ }^{6}$ Inevitably, it is a subjective judgment as to how many auditors are deemed to be big auditors. As a robustness check, we alternatively classify the largest eight (Chen et al., 2011) or the largest 15 auditors (Firth et al., 2011) as big auditors. Our main findings are robust to these alternative definitions.
} 
misreporting (Cao et al., 2012; Kryzanowski \& Zhang, 2013). We also control for the existence of an audit committee within the firm (Audit committee), which is a dummy variable, and the financial expertise of the board (AF background), which is measured by the proportion of board members who have either an accounting or financial background, following a large body of literature that examines the impact of these two factors on earnings/financial reporting quality (e.g., DeFond \& Jiambalvo, 1991; Agrawal \& Chadha, 2005; Firth et al., 2011). Finally, we control for the equity ownership by the largest blockholder (Top shares), following Firth et al. (2011).

Detailed descriptions of the key variables used in this paper are listed in Appendix A.

\section{Empirical Results}

\subsection{Summary Statistics}

We report the yearly distribution of our restatement sample firms in Table 2.

Restatements by family-controlled firms account for 36 of the total 151 restatements (or 23.8\%) in our sample. On average about $3.0 \%$ of family-controlled firms restate their financial reports each year (column (d)), which is significantly lower than the overall percentage of restatements at about 4.5\% (column (b)). An alternative comparison also shows the lower likelihood of restatement by family-controlled firms than by nonfamily-controlled firms. Across the whole market, family-controlled firms account for about 35.9\% of all listed firms during our sample period (column (e)), but restatements by family firms represent only about $23.8 \%$ of all restatements announced (column (f)). Even in the year 2008, when the ratio of family restatements to all restatements is at its highest level, only less than one third (31.8\%) of all restatements are announced by family-controlled firms. 
Table 2 Sample distribution

This table reports the distribution of sample firms (restatement firms only) by year and by whether they are family-controlled firms.

\begin{tabular}{|c|c|c|c|c|c|c|}
\hline Year & $\begin{array}{l}\text { Number of } \\
\text { restatements }\end{array}$ & $\begin{array}{l}\text { Ratio of restatements } \\
\text { all listed firms (\%) }\end{array}$ & $\begin{array}{c}\text { Number of } \\
\text { family restatements }\end{array}$ & $\begin{array}{l}\text { Ratio of family } \\
\text { restatements to all } \\
\text { family firms (\%) }\end{array}$ & $\begin{array}{l}\text { Ratio of family firms } \\
\text { to all listed firms (\%) }\end{array}$ & $\begin{array}{l}\text { Ratio of family } \\
\text { restatements to all } \\
\text { restatements (\%) }\end{array}$ \\
\hline & $\mathrm{a}$ & $\mathrm{b}$ & c & $\mathrm{d}$ & $\mathrm{e}$ & $\mathrm{f}$ \\
\hline 2004 & 10 & 3.0 & 1 & 1.1 & 26.6 & 10.0 \\
\hline 2005 & 31 & 7.9 & 4 & 3.5 & 29.2 & 12.9 \\
\hline 2006 & 26 & 6.1 & 7 & 5.7 & 29.1 & 26.9 \\
\hline 2007 & 16 & 3.4 & 4 & 2.7 & 31.9 & 25.0 \\
\hline 2008 & 22 & 4.1 & 7 & 3.4 & 38.4 & 31.8 \\
\hline 2009 & 20 & 3.4 & 6 & 2.4 & 41.4 & 30.0 \\
\hline 2010 & 26 & 4.1 & 7 & 2.4 & 45.0 & 26.9 \\
\hline Total & 151 & 4.5 & 36 & 3.0 & 35.9 & 23.8 \\
\hline
\end{tabular}


Table 3 Univariate analyses on mean differences between misstatement firms and matching firms

All variables are defined in Appendix A. P-values based on one-tailed t-tests are reported in parentheses. $*, * *$ and $* * *$ indicate significance at the $10 \%, 5 \%$ and $1 \%$ levels, respectively.

\begin{tabular}{|c|c|c|c|c|c|}
\hline & \multicolumn{2}{|c|}{ Misstatement firms } & \multicolumn{2}{|c|}{ Matching firms } & Diff. in means \\
\hline & \multicolumn{2}{|c|}{$(1)$} & \multicolumn{2}{|c|}{$(2)$} & $(3)=(1)-(2)$ \\
\hline & Mean & Std. Dev. & Mean & Std. Dev. & \\
\hline Family & 0.238 & 0.043 & 0.338 & 0.048 & $\begin{array}{c}-0.100 * * * \\
(0.009)\end{array}$ \\
\hline Firm size & 20.767 & 0.906 & 20.957 & 1.044 & $\begin{array}{c}-0.190^{*} \\
(0.093)\end{array}$ \\
\hline Leverage & 0.903 & 0.808 & 0.690 & 0.953 & $\begin{array}{c}0.213^{* *} \\
(0.012)\end{array}$ \\
\hline ROA & 0.024 & 0.014 & 0.024 & 0.013 & $\begin{array}{c}0.000 \\
(0.979)\end{array}$ \\
\hline Top shares & 0.215 & 0.140 & 0.242 & 0.162 & $\begin{array}{c}-0.027^{* * *} \\
(0.006)\end{array}$ \\
\hline Negative EPS & 0.264 & 0.442 & 0.113 & 0.318 & $\begin{array}{c}0.151^{* * *} \\
(0.000)\end{array}$ \\
\hline Reform & 0.528 & 0.501 & 0.572 & 0.496 & $\begin{array}{c}-0.044 \\
(0.216) \\
\end{array}$ \\
\hline Outside directors & 0.359 & 0.059 & 0.360 & 0.065 & $\begin{array}{c}-0.001 \\
(0.941)\end{array}$ \\
\hline Big auditor & 0.205 & 0.406 & 0.265 & 0.443 & $\begin{array}{c}-0.060 * \\
(0.088) \\
\end{array}$ \\
\hline MAO & 0.179 & 0.384 & 0.033 & 0.180 & $\begin{array}{c}0.146 * * * \\
(0.000)\end{array}$ \\
\hline Audit committee & 0.464 & 0.500 & 0.470 & 0.501 & $\begin{array}{l}-0.006 \\
(0.454) \\
\end{array}$ \\
\hline AF background & 0.290 & 0.227 & 0.317 & 0.196 & $\begin{array}{l}-0.027 \\
(0.139)\end{array}$ \\
\hline Obs. & \multicolumn{2}{|c|}{151} & \multicolumn{2}{|c|}{151} & \\
\hline
\end{tabular}


Table 3 presents the summary statistics of the characteristics of the restatement and matching firms. Note that all variables in Table 3 are measured in the year when the misstatement occurs.

Family firms account for about $23.8 \%$ of the misstatement firms and about $33.8 \%$ of the matching firms. In other words, compared to matching firms, misstatement firms are less likely to be family firms. The difference is significant at the $1 \%$ level. Misstatement firms on average are slightly smaller than matching firms as measured by total assets. Misstatement firms have a substantially higher debt level than matching firms, which is consistent with prior studies (e.g., Kinney \& McDaniel, 1989; DeFond \& Jiambalvo, 1991). Firms with net loss in the prior year (Negative EPS) are significantly more likely to misstate their financial reports. This is not surprising because loss-making firms have strong incentives to manipulate their accounting numbers in order to conceal their true financial performance and/or to avoid the ST designation. Noticeably, there are no significant differences between misstatement firms and matching firms in several key corporate governance variables, such as board independence, the existence of an audit committee, and board members' accounting and financial expertise. These variables are found to be negatively associated with the likelihood of misstatements in Western countries (Agrawal \& Chadha, 2005, Cao et al., 2012; Kryzanowski \& Zhang, 2013). The data thus indicates that these corporate governance mechanisms fail to deter Chinese firms from misstating financial reports. Consistent with prior studies, misstatement firms are less likely to hire a big external auditor and more likely to be issued with a modified auditor's opinion prior to misstatement.

\subsection{Family Control and Misstatements}

We test our first hypothesis H1 by estimating the regression model specified in Eq. (1) and report the results in Table 4. 
Table 4 Family control and the likelihood of a firm misstating its financial report

This table presents logistic regression results on the relationship between family control and the likelihood of a firm misstating its financial report. All variables are defined in Table 1 . $P$-values based on White standard errors are reported next to coefficients. $*, * *$ and $* * *$ indicate significance at the $10 \%, 5 \%$ and $1 \%$ levels, respectively.

\begin{tabular}{|c|c|c|c|c|}
\hline \multirow[t]{3}{*}{ Dependent variable: } & \multicolumn{4}{|c|}{ Misstate } \\
\hline & \multicolumn{2}{|c|}{$(1)$} & \multicolumn{2}{|c|}{ (2) } \\
\hline & coefficient & $p$-value & coefficient & $p$-value \\
\hline Family & $-0.744 * * *$ & 0.010 & $-0.733^{* *}$ & 0.018 \\
\hline Firm size & & & -0.211 & 0.187 \\
\hline Leverage & & & $0.136 * *$ & 0.032 \\
\hline ROA & & & -7.434 & 0.516 \\
\hline Top share & & & $-1.734 * *$ & 0.046 \\
\hline Negative EPS & & & $0.435^{* *}$ & 0.014 \\
\hline Reform & & & 0.266 & 0.289 \\
\hline Outside directors & & & 0.790 & 0.724 \\
\hline Big auditor & & & -0.259 & 0.148 \\
\hline MAO & & & $2.187^{* * *}$ & 0.000 \\
\hline Audit committee & & & -0.079 & 0.810 \\
\hline AF background & & & 0.515 & 0.422 \\
\hline Constant & 0.071 & 0.962 & 3.850 & 0.269 \\
\hline Year effect & \multicolumn{2}{|c|}{ Included } & \multicolumn{2}{|c|}{ Included } \\
\hline Industry effect & \multicolumn{2}{|c|}{ Included } & \multicolumn{2}{|c|}{ Included } \\
\hline Pseudo R-squared & \multicolumn{2}{|c|}{$2.12 \%$} & \multicolumn{2}{|c|}{$7.53 \%$} \\
\hline Wald Chi2 & \multicolumn{2}{|c|}{$5.48^{* *}$} & \multicolumn{2}{|c|}{$28.68 * * *$} \\
\hline Obs. & \multicolumn{2}{|c|}{302} & \multicolumn{2}{|c|}{302} \\
\hline
\end{tabular}


The dependent variable in both columns (1) and (2) is the likelihood of a firm misstating its financial report. In column (1), where the family control dummy is the only independent variable other than year and industry fixed effects, we find that family control has a significant and negative effect (coef. $=-0.744, p=0.010$ ) on accounting misstatements. In column (2), we control for a set of variables including firm-specific characteristics, auditor attributes, and firm performance. The coefficient of Family remains negative and significant, although its magnitude (-0.733 vs. -0.744$)$ and statistical significance ( $p=0.018$ vs. $p=0.010)$ become slightly lower. These findings provide support for our prediction in H1 that familycontrolled firms are less likely than nonfamily-controlled firms to misstate their financial statements, even after controlling for other factors.

With respect to control variables, the results are mostly consistent with the univariate statistics reported in Table 3. The main differences are for firm size and auditor quality. Neither the coefficient of Firm size nor Big auditor in Table 4 is significant, indicating that these two factors do not significantly affect the likelihood of accounting misstatements after controlling for family control and other firm-specific factors. While they are found to be different between misstatement firms and control firms in Table 3, these results shouldn't be too surprising because the difference in firm size and auditor quality between these two group of firms is only marginal ( $p=0.093$ and $p=0.088$, respectively, in Table 3).

\subsection{Family Control and Market Reactions to Restatements}

\subsubsection{Short-term reactions}

In this subsection, we test $\mathrm{H} 2$ in two steps. We first compare short-term market reactions to family firm restatements and to nonfamily firm restatements. The univariate tests are done over three event windows, $[0,+1],[-1,+1]$, and $[-3,+3]$, with day 0 being the announcement day. The results are reported in Table 5. 
Table 5 Comparison of market reactions to restatements by family firms and by nonfamily firms

This table presents univariate tests of the different market reactions to restatements announced by family firms and by nonfamily firms, for short windows surrounding announcements (column (6)). CAR is the cumulative abnormal return. ARV is the abnormal return variance. ATV is the abnormal trading volume. ABAS is the abnormal bid-ask spread. This table also tests whether the market reactions are different from zero for restatements by family firms and nonfamily firms, respectively. $P$-values in columns (3) and (5) are based on HO=0 (CAR) and HO=1 (ARV, ATV, and ABAS). Significances are based on $p$ values using the two-tailed t-test, except for those in column (6) which are based on one-tailed t-test.

\begin{tabular}{|c|c|c|c|c|c|c|c|}
\hline & $\begin{array}{c}\text { All } \\
\text { restatements }\end{array}$ & $\begin{array}{c}\text { Family firm } \\
\text { restatements }\end{array}$ & $p$-value & $\begin{array}{c}\text { Nonfamily firm } \\
\text { restatements }\end{array}$ & $p$-value & Diff. in means & $\begin{array}{c}p \text {-value } \\
(\mathrm{HO} \text { : Diff = 0) }\end{array}$ \\
\hline & $(1)$ & $(2)$ & (3) & (4) & (5) & $(6)=(2)-(4)$ & (7) \\
\hline $\operatorname{CAR}[0,+1](\%)$ & -1.481 & -2.603 & 0.001 & -1.130 & 0.016 & $-1.473 * *$ & 0.044 \\
\hline $\operatorname{CAR}[-1,+1](\%)$ & -2.122 & -3.601 & 0.001 & -1.660 & 0.004 & $-1.941 * *$ & 0.034 \\
\hline CAR $[-3,+3](\%)$ & -2.665 & -4.575 & 0.006 & -2.067 & 0.003 & $-2.508^{*}$ & 0.056 \\
\hline ARV $[0,+1]$ & 2.661 & 2.700 & 0.000 & 2.221 & 0.000 & $0.479 * *$ & 0.024 \\
\hline $\operatorname{ARV}[-1,+1]$ & 1.499 & 1.791 & 0.000 & 1.408 & 0.000 & $0.383^{* *}$ & 0.039 \\
\hline $\operatorname{ARV}[-3,+3]$ & 1.538 & 1.898 & 0.000 & 1.437 & 0.008 & $0.461 * *$ & 0.030 \\
\hline $\operatorname{ATV}[0,+1]$ & 1.462 & 1.949 & 0.000 & 1.310 & 0.000 & $0.639 * *$ & 0.012 \\
\hline ATV $[-1,+1]$ & 1.401 & 1.924 & 0.000 & 1.238 & 0.000 & $0.686 * * *$ & 0.005 \\
\hline ATV $[-3,+3]$ & 1.432 & 2.019 & 0.000 & 1.248 & 0.000 & $0.771 * * *$ & 0.005 \\
\hline ABAS $[0,+1]$ & 2.508 & 2.793 & 0.000 & 1.588 & 0.002 & $1.205^{* *}$ & 0.045 \\
\hline ABAS $[-1,+1]$ & 2.323 & 2.633 & 0.000 & 1.324 & 0.007 & $1.309 * *$ & 0.021 \\
\hline ABAS $[-3,+3]$ & 2.127 & 2.395 & 0.000 & 1.262 & 0.009 & $1.133^{* * *}$ & 0.008 \\
\hline
\end{tabular}


We then use market reactions during the window $[-1,+1]$ as our dependent variables to estimate our baseline regression model, as specified in Eq. (2), and report the regression results in Table 6 . In unreported tests, we use market reactions over windows $[0,+1]$ and $[-3$, +3 ] as dependent variables and find that our main findings remain qualitatively unchanged.

Short-term market reactions, measured by CAR, ARV, ATV, and ABAS, to all restatements, family firm restatements, and nonfamily restatements are reported in column (1), column (2), and column (4), respectively. Consistent with our expectation, CARs are negative while ARVs, ATVs, and ABASs are all positive for both family firm restatements and nonfamily firm restatements. All the p-values in column (3) and column (5) are significant at the $1 \%$ level, with only one exception (CAR $[0,+1]$ for nonfamily firm restatements) which is significant at the $5 \%$ level. These statistics show that accounting restatements are associated with significantly negative short-term abnormal stock returns and increased investor uncertainty about the firms' future performance.

Our focus is the differences in market reactions to family firm restatements and nonfamily firm restatements, as reported in column (6). As we can see, compared to restatements announced by nonfamily firms, restatements announced by family firms are associated with more negative short-term abnormal stock returns. For example, over the three-day window, CAR $[-1,+1]$ is $-3.601 \%$ for family firm restatements but only $-1.660 \%$ for nonfamily firm restatements. The difference is significant at the $5 \%$ level $(p=0.034)$. The differences for the other three measures are all significant as well. For example, ARV $[-1,+1]$ for family firm restatements is 1.791 , which is significantly larger than ARV $[-1,+1]$ for nonfamily firm restatements $(p=0.039)$.

In summary, the data in Table 5 shows that, although both family firm restatements and nonfamily firm restatements result in negative short-term abnormal stock returns and increase uncertainty among investors about the restatement firms' future performance, the 
consequences are significantly more severe for family firm restatements. The statistics in Table 5 are consistent with our prediction in $\mathrm{H} 2$.

We further test $\mathrm{H} 2$ with multivariate regressions and report the results in Table 6.

Our purpose here is to test any differences in market reactions between family firm restatements and nonfamily firm restatements, and thus the sample in Table 6 contains all restatement firms but no matching firms. We run four sets of regressions using CAR, ARV, ATV, and ABAS, as the dependent variable, respectively. For each of the four market reaction measures we estimate two regression models: one uses the family control dummy as the only independent variable, apart from year and industry fixed effects, and the other model also includes a set of control variables.

As can be seen from Table 6, the coefficient of Family is significant in all eight model specifications. The sign of the coefficient is consistent with the statistics reported in column (6) of Table 5. Specifically, the coefficient of Family is negative when CAR is the dependent variable and is positive when ARV, ATV, or ABAS is the dependent variable. The magnitude of the coefficient of Family becomes even larger when control variables are included in the regression, e.g., -2.181 in column (2) compared to -1.777 in column (1).

Taken together, the findings in Table 5 and Table 6 indicate that when a firm announces an accounting restatement, being family-controlled is associated with significantly more negative short-term stock returns (CAR), higher abnormal return variance (ARV), higher abnormal trading volume (ATV), and larger abnormal bid-ask spread (ABAS). These findings suggest that investors are more concerned about the deterioration in accounting earnings quality in family firms and consequently react more strongly to restatements announced by family firms than those by nonfamily firms. The findings thus support our hypothesis $H 2$. 
Table 6 Family control and market reactions surrounding restatement announcements

This table presents regression results on the relationship between family control and short-window market reactions surrounding restatement announcements. All variables are defined in Appendix. $P$-values based on White standard errors (White, 1980) are reported in parentheses. $*, * *$ and $* * *$ indicate significance at the $10 \%, 5 \%$ and $1 \%$ levels, respectively.

\begin{tabular}{|c|c|c|c|c|c|c|c|c|}
\hline \multirow[t]{2}{*}{ Dependent variables: } & \multicolumn{2}{|c|}{$\begin{array}{l}\text { Cumulative abnormal return } \\
\qquad \text { CAR }[-1,+1]\end{array}$} & \multicolumn{2}{|c|}{$\begin{array}{c}\text { Abnormal return variance } \\
\text { ARV }[-1,+1]\end{array}$} & \multicolumn{2}{|c|}{$\begin{array}{c}\text { Abnormal trading volume } \\
\text { ATV }[-1,+1]\end{array}$} & \multicolumn{2}{|c|}{$\begin{array}{c}\text { Abnormal bid-ask spread } \\
\text { ABAS }[-1,+1]\end{array}$} \\
\hline & $(1)$ & $(2)$ & (3) & (4) & (5) & $(6)$ & (7) & (8) \\
\hline Family & $\begin{array}{c}-1.777 * * \\
(0.032) \\
\end{array}$ & $\begin{array}{c}-2.181 * * \\
(0.011) \\
\end{array}$ & $\begin{array}{c}0.376 * * \\
(0.045)\end{array}$ & $\begin{array}{l}0.396 * * \\
(0.049)\end{array}$ & $\begin{array}{c}0.716 * * * \\
(0.000) \\
\end{array}$ & $\begin{array}{c}0.771 * * * \\
(0.000) \\
\end{array}$ & $\begin{array}{c}1.817 * * \\
(0.049)\end{array}$ & $\begin{array}{l}1.911 * * \\
(0.038)\end{array}$ \\
\hline Firm size & & $\begin{array}{c}1.293 \\
(0.430) \\
\end{array}$ & & $\begin{array}{l}-0.243 \\
(0.292) \\
\end{array}$ & & $\begin{array}{l}-0.154 \\
(0.434) \\
\end{array}$ & & $\begin{array}{c}-0.999 * * \\
(0.020) \\
\end{array}$ \\
\hline Leverage & & $\begin{array}{c}-0.884 * * \\
(0.031) \\
\end{array}$ & & $\begin{array}{l}0.221^{* *} \\
(0.039)\end{array}$ & & $\begin{array}{l}0.120 * \\
(0.065)\end{array}$ & & $\begin{array}{c}0.052 \\
(0.764) \\
\end{array}$ \\
\hline Top share & & $\begin{array}{l}0.041^{*} \\
(0.066)\end{array}$ & & $\begin{array}{l}-0.427 \\
(0.583) \\
\end{array}$ & & $\begin{array}{c}0.402 \\
(0.532) \\
\end{array}$ & & $\begin{array}{l}-0.729 \\
(0.804) \\
\end{array}$ \\
\hline Negative EPS & & $\begin{array}{l}-1.468 * \\
(0.097) \\
\end{array}$ & & $\begin{array}{l}0.256^{*} \\
(0.061) \\
\end{array}$ & & $\begin{array}{c}0.064 \\
(0.852) \\
\end{array}$ & & $\begin{array}{c}1.090 \\
(0.271) \\
\end{array}$ \\
\hline MAO & & $\begin{array}{l}-1.075 \\
(0.113) \\
\end{array}$ & & $\begin{array}{l}0.460 * \\
(0.098) \\
\end{array}$ & & $\begin{array}{c}0.268 * * \\
(0.055)\end{array}$ & & $\begin{array}{l}1.200 * \\
(0.095) \\
\end{array}$ \\
\hline Outside directors & & $\begin{array}{c}0.052 \\
(0.894) \\
\end{array}$ & & $\begin{array}{c}0.080 \\
(0.665) \\
\end{array}$ & & $\begin{array}{c}0.025 \\
(0.876) \\
\end{array}$ & & $\begin{array}{c}-0.021 \\
(0.751) \\
\end{array}$ \\
\hline Constant & $\begin{array}{c}-0.717^{*} \\
(0.060)\end{array}$ & $\begin{array}{c}-5.610^{*} \\
(0.076)\end{array}$ & $\begin{array}{c}1.409 * * * \\
(0.000)\end{array}$ & $\begin{array}{c}-3.548 * * \\
(0.045)\end{array}$ & $\begin{array}{c}1.231^{* * *} \\
(0.000)\end{array}$ & $\begin{array}{c}-2.043^{*} \\
(0.066)\end{array}$ & $\begin{array}{c}1.534^{* * *} \\
(0.001)\end{array}$ & $\begin{array}{c}23.340 * * \\
(0.015)\end{array}$ \\
\hline Year effect & Included & Included & Included & Included & Included & Included & Included & Included \\
\hline Industry effect & Included & Included & Included & Included & Included & Included & Included & Included \\
\hline Obs. & 151 & 151 & 151 & 151 & 151 & 151 & 151 & 151 \\
\hline Adj. R-squared & $3.14 \%$ & $7.93 \%$ & $5.52 \%$ & $6.41 \%$ & $12.84 \%$ & $14.46 \%$ & $2.90 \%$ & $15.19 \%$ \\
\hline F-statistic & $4.69 * *$ & $2.74^{* *}$ & $7.66 * * *$ & $2.66^{* *}$ & $12.78 * * *$ & $2.65^{* *}$ & $2.11^{* *}$ & $1.75^{* *}$ \\
\hline
\end{tabular}




\subsubsection{Expropriation risk and the impact of family control}

In this subsection we perform additional tests to examine whether controlling for the risk of expropriation by shareholders perceived by investors has any effect on the relationship between family control and short-term market reactions (i.e., H3). The tests are based on regression models specified in Eq. (3). More specifically, we add to our baseline regression models specified in Eq. (2) a stand-alone variable as a proxy for expropriation risk and its interaction with family control. The regression results are reported in Table 7.

As in Table 6, we run four sets of regressions using CAR, ARV, ATV, and ABAS, as the dependent variable, respectively. And for each dependent variable we estimate two regression models: one uses the ultimate largest shareholder's control-ownership wedge as the proxy for expropriation risk and the other uses corporate opacity as the proxy.

In each of the eight models, the coefficient of Family remains significant and keeps the sign of its corresponding coefficient in Table 6. The results indicate that even for firms with low wedge and low opacity (i.e., firms with relatively low expropriation risk), family control still triggers stronger reactions from investors. The coefficient of the stand-alone variable Ownership wedge is significant across all four models and has the same sign as that of Family. This indicates that control-ownership wedge, like family control, also increases investor concern about agency problems and uncertainty. The coefficient of the stand-alone variable Corporate opacity, although having the same sign as that of Ownership wedge, is not significant across all four models. The results suggest that when market reaction is measured by CAR or ATV, the level of corporate opacity has no significant effect on how investors react to restatements announced by nonfamily firms. Our main interest is the interaction terms Family*Ownership wedge and Family*Corporate opacity, which capture the incremental effect of expropriation risk on market reactions to family firm restatements. 
Table 7 Expropriation risk and the impact of family control on market reactions to restatement announcements

This table presents regression results of how the impact of family control on short-window market reactions surrounding restatement announcements is affected by the potential risk of expropriation by controlling families. The potential expropriation risk is measured by control-ownership wedge and corporate opacity. All variables are defined in Appendix. $P$-values based on White standard errors (White, 1980$)$ are reported in parentheses. $*, * *$ and $* * *$ indicate significance at the $10 \%, 5 \%$ and $1 \%$ levels, respectively.

\begin{tabular}{|c|c|c|c|c|c|c|c|c|}
\hline \multirow[t]{2}{*}{ Dependent variables: } & \multicolumn{2}{|c|}{$\begin{array}{l}\text { Cumulative abnormal return } \\
\text { CAR }[-1,+1]\end{array}$} & \multicolumn{2}{|c|}{$\begin{array}{c}\text { Abnormal return variance } \\
\operatorname{ARV}[-1,+1] \\
\end{array}$} & \multicolumn{2}{|c|}{$\begin{array}{c}\text { Abnormal trading volume } \\
\text { ATV }[-1,+1]\end{array}$} & \multicolumn{2}{|c|}{$\begin{array}{c}\text { Abnormal bid-ask spread } \\
\text { ABAS }[-1,+1]\end{array}$} \\
\hline & $(1)$ & $(2)$ & (3) & (4) & (5) & (6) & (7) & (8) \\
\hline Family & $\begin{array}{l}-1.148^{*} \\
(0.053)\end{array}$ & $\begin{array}{l}-3.947^{*} \\
(0.052)\end{array}$ & $\begin{array}{l}0.679 * * \\
(0.023)\end{array}$ & $\begin{array}{l}1.821^{* *} \\
(0.022)\end{array}$ & $\begin{array}{c}0.900 * * * \\
(0.000)\end{array}$ & $\begin{array}{l}1.099 * \\
(0.091)\end{array}$ & $\begin{array}{l}0.538^{*} \\
(0.092)\end{array}$ & $\begin{array}{c}3.123^{* *} \\
(0.030)\end{array}$ \\
\hline Family * Ownership wedge & $\begin{array}{c}-0.106 * * \\
(0.042)\end{array}$ & & $\begin{array}{l}0.752 * * \\
(0.026)\end{array}$ & & $\begin{array}{c}0.430 * * \\
(0.035) \\
\end{array}$ & & $\begin{array}{l}1.023 * * \\
(0.046)\end{array}$ & \\
\hline Family * Corporate opacity & & $\begin{array}{l}-4.252^{*} \\
(0.064)\end{array}$ & & $\begin{array}{l}2.696 * * \\
(0.045)\end{array}$ & & $\begin{array}{l}0.929 * \\
(0.086)\end{array}$ & & $\begin{array}{c}8.610 * * \\
(0.020)\end{array}$ \\
\hline Ownership wedge & $\begin{array}{c}-0.106 * * \\
(0.029)\end{array}$ & & $\begin{array}{l}0.181^{*} \\
(0.057)\end{array}$ & & $\begin{array}{l}0.101^{*} \\
(0.063)\end{array}$ & & $\begin{array}{c}1.182 * * \\
(0.033)\end{array}$ & \\
\hline Corporate Opacity & & $\begin{array}{l}-3.668 \\
(0.204)\end{array}$ & & $\begin{array}{l}0.757^{*} \\
(0.093)\end{array}$ & & $\begin{array}{c}1.229 \\
(0.430)\end{array}$ & & $\begin{array}{l}8.583^{* *} \\
(0.020)\end{array}$ \\
\hline Firm size & $\begin{array}{c}1.031 \\
(0.157)\end{array}$ & $\begin{array}{c}1.333 \\
(0.277)\end{array}$ & $\begin{array}{c}-0.207 \\
(0.358)\end{array}$ & $\begin{array}{c}-0.310 \\
(0.210)\end{array}$ & $\begin{array}{c}-0.160 \\
(0.416)\end{array}$ & $\begin{array}{c}0.255 \\
(0.225)\end{array}$ & $\begin{array}{c}-1.344^{*} \\
(0.096)\end{array}$ & $\begin{array}{c}-1.503^{*} \\
(0.067)\end{array}$ \\
\hline Leverage & $\begin{array}{c}-0.833^{*} \\
(0.059) \\
\end{array}$ & $\begin{array}{c}-0.840 * * \\
(0.048)\end{array}$ & $\begin{array}{l}0.203^{*} \\
(0.051)\end{array}$ & $\begin{array}{c}0.227^{* *} \\
(0.048)\end{array}$ & $\begin{array}{l}0.119 * \\
(0.067)\end{array}$ & $\begin{array}{c}0.166^{*} \\
(0.063)\end{array}$ & $\begin{array}{c}0.033 \\
(0.605) \\
\end{array}$ & $\begin{array}{c}0.030 \\
(0.617)\end{array}$ \\
\hline Top share & $\begin{array}{c}0.048 * * \\
(0.046)\end{array}$ & $\begin{array}{l}0.041^{*} \\
(0.067) \\
\end{array}$ & $\begin{array}{c}-0.308 \\
(0.694) \\
\end{array}$ & $\begin{array}{c}-0.440 \\
(0.569) \\
\end{array}$ & $\begin{array}{c}0.358 \\
(0.589) \\
\end{array}$ & $\begin{array}{c}0.471 \\
(0.460) \\
\end{array}$ & $\begin{array}{c}-1.754 \\
(0.460)\end{array}$ & $\begin{array}{c}-0.794 \\
(0.794)\end{array}$ \\
\hline Negative EPS & $\begin{array}{c}-1.411^{*} \\
(0.098)\end{array}$ & $\begin{array}{c}-1.425 \\
(0.101) \\
\end{array}$ & $\begin{array}{l}0.196 * \\
(0.074)\end{array}$ & $\begin{array}{c}0.244^{* *} \\
(0.042)\end{array}$ & $\begin{array}{c}0.071 \\
(0.774) \\
\end{array}$ & $\begin{array}{c}0.067 \\
(0.798) \\
\end{array}$ & $\begin{array}{c}0.733 \\
(0.169) \\
\end{array}$ & $\begin{array}{c}0.601 \\
(0.203) \\
\end{array}$ \\
\hline MAO & $\begin{array}{c}-1.340 * \\
(0.089)\end{array}$ & $\begin{array}{c}-1.409 * \\
(0.083)\end{array}$ & $\begin{array}{c}0.491^{*} \\
(0.077)\end{array}$ & $\begin{array}{c}0.420 * \\
(0.094)\end{array}$ & $\begin{array}{c}0.306 \\
(0.180)\end{array}$ & $\begin{array}{c}0.438 \\
(0.157)\end{array}$ & $\begin{array}{l}0.860 * \\
(0.092)\end{array}$ & $\begin{array}{c}1.160 * \\
(0.077)\end{array}$ \\
\hline Outside directors & $\begin{array}{c}0.044 \\
(0.454) \\
\end{array}$ & $\begin{array}{c}0.023 \\
(0.690) \\
\end{array}$ & $\begin{array}{c}0.122 \\
(0.492) \\
\end{array}$ & $\begin{array}{c}0.120 \\
(0.506) \\
\end{array}$ & $\begin{array}{c}-0.087 \\
(0.573) \\
\end{array}$ & $\begin{array}{l}-0.103 \\
(0.375) \\
\end{array}$ & $\begin{array}{c}0.029 \\
(0.500) \\
\end{array}$ & $\begin{array}{c}0.013 \\
(0.762) \\
\end{array}$ \\
\hline Constant & $\begin{array}{c}4.822 * * \\
(0.023)\end{array}$ & $\begin{array}{l}7.315^{*} \\
(0.065)\end{array}$ & $\begin{array}{c}-3.383^{* *} \\
(0.045)\end{array}$ & $\begin{array}{c}-5.366 * * \\
(0.028)\end{array}$ & $\begin{array}{c}-1.777^{*} \\
(0.065)\end{array}$ & $\begin{array}{c}-2.856^{* *} \\
(0.050)\end{array}$ & $\begin{array}{c}27.956 * \\
(0.073)\end{array}$ & $\begin{array}{c}28.225^{*} \\
(0.060)\end{array}$ \\
\hline
\end{tabular}




\begin{tabular}{|c|c|c|c|c|c|c|c|c|}
\hline Year effect & Included & Included & Included & Included & Included & Included & Included & Included \\
\hline Industry effect & Included & Included & Included & Included & Included & Included & Included & Included \\
\hline Obs. & 151 & 151 & 151 & 151 & 151 & 151 & 151 & 151 \\
\hline Adj. R-squared & $6.40 \%$ & $8.58 \%$ & $4.04 \%$ & $7.03 \%$ & $10.77 \%$ & $14.60 \%$ & $5.41 \%$ & $14.53 \%$ \\
\hline F-statistic & $2.03 * *$ & $2.77^{* *}$ & $1.93 * *$ & $2.38 * *$ & $2.02 * *$ & $2.42 * *$ & $1.94 * *$ & $2.92 * * *$ \\
\hline
\end{tabular}


The coefficient of either Family*Ownership wedge or Family*Corporate opacity is statistically significant in all eight model specifications. The coefficients of the interaction terms have the same sign as the corresponding coefficients of the stand-alone Family, i.e., negative when CAR is the dependent variable and positive when ARV, ATV, or ABAS is the dependent variable. These results indicate that the stronger market reactions to family firm restatements become even more pronounced as the expropriation risk increases.

Overall, the findings in Table 7 indicate that as the risk of expropriation by controlling shareholders increases, investors have even greater concerns about controlling shareholder's credibility, agency problems, and uncertainty following restatements. This will further strengthen the impact of family control on market reactions to restatement announcements. These findings are consistent with our prediction in $H 3$.

\subsection{Additional Tests}

\subsubsection{The timeline}

To investigate the effect of restatement over the longer term, we perform two sets of tests in this subsection. We first follow up our tests in Section 4.3 to compare the difference in market reactions (i.e., return variance, trading volume, and bid-ask spread) before the restatement announcement (window $[-120,-21]$ ) and after announcement (window [+21, +120]), for family restatement firms and nonfamily restatement firms, respectively. See Figure 1A for the timeline. We then follow the large body of literature to examine the drop in the information content of earnings (measured by ERC) after the restatement announcement, by comparing the ERC in one year before and one year after the restatement announcements. Because we only have annual earnings data, we focus on yearly ERC rather than quarterly ERC, as in some prior studies such as Wilson (2008) and Chen, Cheng, and Lo (2014). See Figure 1B for the timeline. 
Figure 1 Illustration of timeline

Figure 1A: Timeline of market reaction tests

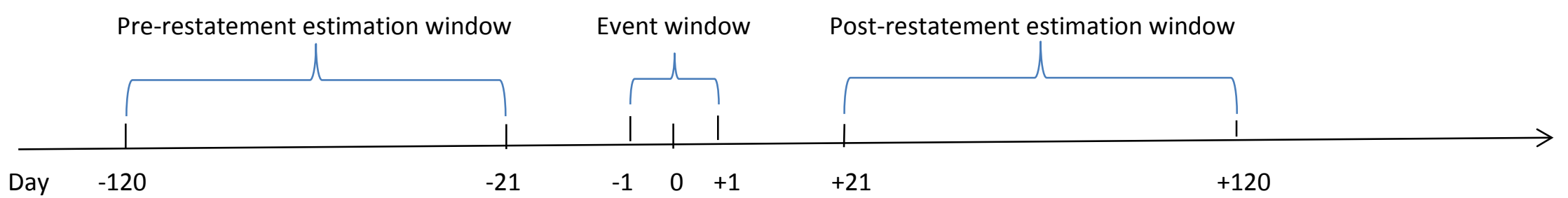

Figure 1B: Timeline of earnings informativeness tests

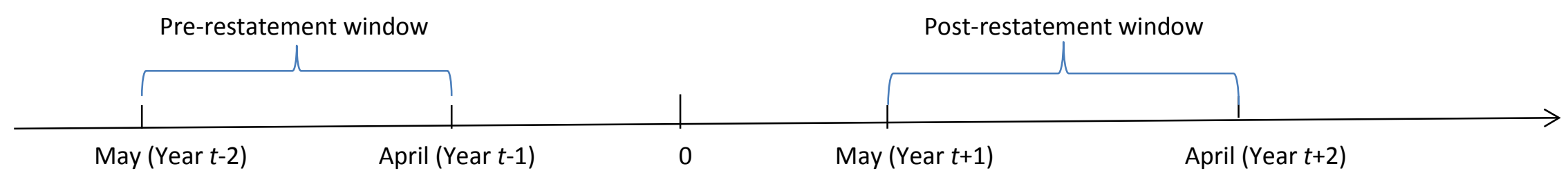




\subsubsection{Longer-term market reactions}

In subsection 4.3.1, we examine the differences in market reactions to family firm restatements and nonfamily firm restatements over three short-term windows, $[0,+1],[-1$, $+1]$, and $[-3,+3]$. In this subsection, we test whether the stronger market reactions to family firm restatements are still observed over a longer period. The literature provides mixed empirical evidence on whether the effects of restatements (e.g., the drop in ERC) are shortlived (e.g., Wilson, 2008; Chen et al., 2014). Although it is not our intention to find out exactly how long the effects of restatements last, the tests we perform in this subsection may provide complementary evidence to enhance our understanding of the issue.

We first adopt a difference-in-difference approach. We compare the pre- and postrestatement stock return variance, trading volume, and bid-ask spread for restatement firms and matching firms (i.e., nonrestatement firms), respectively. We then compare the changes (from pre- to post-restatement period) in these three measures between restatement firms and matching firms. Because we identify each matching firm based on industry, size, IPO year, and stock exchange, such a comparison also controls for the influence of these factors. The results are reported in Panel A of Table 8. The left-hand side of Panel A presents the results for 36 family restatement firms and 36 matching firms. The right-hand side presents the results for 115 nonfamily restatement firms and their corresponding matching firms. The preand post-restatement estimation window is $[-120,-21]$ and $[+21,+120]$, respectively, where day 0 is the restatement announcement day.

We take daily stock return variance as an example. For family restatement firms, the average return variance increases significantly from 3.311 in the pre-restatement estimation window to 3.628 in the post-restatement window (diff. $=0.317, p=0.008$ ). During the same period, although the matching firms also experience an increase in return variance, their increase is insignificant (diff. $=0.129, p=0.182$ ). The difference in the change in return 


\section{Table 8 Longer-term effects of restatement announcements}

Panel A: Difference-in-difference tests

Panel A of this table present the difference-in-difference test results of longer term effects of restatement announcements on market reactions, i.e., daily stock return volatility, daily trading volume, and bid-ask spread. The left-hand side of the table reports the statistics of the family restatement firms (36 firms) and their matching firms. The right-hand side of the table reports the nonfamily restatement firms (115 firms) and their corresponding matching firms. The pre-restatement estimation window is $[-120,-21]$ and the post-restatement estimation window is [+21, +120$]$, with day 0 being the restatement announcement day. Stock return variance is the variance of the residual returns from each firm's market model; trading volume is the number of shares traded on the day divided by the number of tradable shares outstanding on that day; bid-ask spread is the average relative spread (i.e., absolute spread divided by the average of bid and ask) over the test period measured in hourly intervals. Significances are based on $p$-values using the one-tailed t-test.

\begin{tabular}{|c|c|c|c|c|c|c|c|}
\hline & & \multicolumn{3}{|c|}{ Family restatement firms } & \multicolumn{3}{|c|}{ Nonfamily restatement firms } \\
\hline & & $\begin{array}{l}\text { Pre- } \\
\text { restatement (a) }\end{array}$ & $\begin{array}{l}\text { Post- } \\
\text { restatement (b) }\end{array}$ & $\begin{array}{c}(\mathrm{b})-(\mathrm{a}) \\
(p \text {-value })\end{array}$ & $\begin{array}{l}\text { Pre- } \\
\text { restatement (a) }\end{array}$ & $\begin{array}{l}\text { Post- } \\
\text { restatement (b) }\end{array}$ & $\begin{array}{l}\text { (b) }-(\mathrm{a}) \\
\text { (p-value) }\end{array}$ \\
\hline \multirow{3}{*}{$\begin{array}{l}\text { Stock return } \\
\text { variance }\end{array}$} & Restatement firms (1) & 3.311 & 3.628 & $\begin{array}{c}0.317^{* * *} \\
(0.008)\end{array}$ & 3.201 & 3.306 & $\begin{array}{l}0.105^{*} \\
(0.078)\end{array}$ \\
\hline & Control firms (2) & 2.977 & 3.106 & $\begin{array}{c}0.129 \\
(0.182)\end{array}$ & 3.003 & 3.087 & $\begin{array}{c}0.084 \\
(0.282)\end{array}$ \\
\hline & $(1)-(2)$ & 0.334 & 0.522 & $\begin{array}{l}0.188 * * \\
(0.048)\end{array}$ & 0.198 & 0.219 & $\begin{array}{c}0.021 \\
(0.455)\end{array}$ \\
\hline \multirow{3}{*}{$\begin{array}{l}\text { Trading } \\
\text { volume }\end{array}$} & Restatement firms (1) & 2.382 & 3.196 & $\begin{array}{c}0.814^{* *} \\
(0.030)\end{array}$ & 2.960 & 3.052 & $\begin{array}{c}0.092 \\
(0.340)\end{array}$ \\
\hline & Control firms (2) & 2.344 & 2.678 & $\begin{array}{c}0.334 \\
(0.122)\end{array}$ & 2.768 & 2.896 & $\begin{array}{c}0.128 \\
(0.288)\end{array}$ \\
\hline & $(1)-(2)$ & 0.038 & 0.518 & $\begin{array}{l}0.480 * \\
(0.054) \\
\end{array}$ & 0.192 & 0.156 & $\begin{array}{c}0.036 \\
(0.411) \\
\end{array}$ \\
\hline \multirow{3}{*}{$\begin{array}{l}\text { Bid-ask } \\
\text { spread }\end{array}$} & Restatement firms (1) & 0.236 & 0.337 & $\begin{array}{c}0.101^{* *} \\
(0.033)\end{array}$ & 0.217 & 0.241 & $\begin{array}{c}0.024 \\
(0.209)\end{array}$ \\
\hline & Control firms (2) & 0.209 & 0.258 & $\begin{array}{l}0.049 * \\
(0.098)\end{array}$ & 0.222 & 0.230 & $\begin{array}{c}0.008 \\
(0.433)\end{array}$ \\
\hline & $(1)-(2)$ & 0.027 & 0.079 & $\begin{array}{l}0.052 * \\
(0.064)\end{array}$ & -0.005 & 0.011 & $\begin{array}{c}0.016 \\
(0.218)\end{array}$ \\
\hline
\end{tabular}


variance (or difference-in-difference, marked in bold font in Panel A) between family restatement firms and their matching firms is statistically significant (diff. $=0.188, p=0.048$ ). In contrast, although nonfamily restatement firms also experience a significant increase in return variance from 3.201 to 3.306 (diff. $=0.105, p=0.078$ ), the difference-in-difference is insignificant ( $p=0.455$ ) between nonfamily restatement firms and their matching firms.

These difference-in-difference analyses indicate that while family restatement firms experience a significant increase in stock return variance over a longer window (up to 120 days after the restatement announcement in our tests) compared to their nonrestatement matching firms, there is no significant difference in the change in return variance between nonfamily restatement firms and their matching firms. The results are similar if we look at the changes in trading volume and bid-ask spread.

We next perform tests to directly compare the changes in return variance, trading volume, and bid-ask spread between family restatement firms and nonfamily restatement firms, in addition to comparing the changes between each group of restatement firms and their corresponding nonrestatement matching firms. The results are reported in Panel B of Table 8.

We again take stock return variance as an example to illustrate the findings. For both family restatement firms and nonfamily restatement firms, their return variance in the postrestatement period is significantly larger than that in the pre-restatement period $(p=0.008$ for family firms and $p=0.078$ for nonfamily firms). When we look at the difference in the change, we can see that the increase in return variance is significantly larger for family firms than for nonfamily firms (diff. $=0.212, p=0.030$ ). In other words, the impact of the restatement announcement on return variance increase is more pronounced for family restatement firms than for nonfamily restatement firms. Comparisons in trading volume and bid-ask spread yield similar results. 
Table 8 Longer-term effects of restatement announcements

Panel B: Direct comparison between family restatement firms and nonfamily restatement firms

Panel B presents the statistics using an alternative approach to compare the difference in change in return variance, trading volume, and bid-ask spread between family restatement firms and nonfamily restatement firms. We then compare the changes in these measures between family restatement firms and nonfamily restatement firms, following restatement announcements.

\begin{tabular}{|c|c|c|c|c|}
\hline & & $\begin{array}{l}\text { Pre-restatement } \\
\text { (a) }\end{array}$ & $\begin{array}{l}\text { Post-restatement } \\
\text { (b) }\end{array}$ & $\begin{array}{c}(\mathrm{b})-(\mathrm{a}) \\
(p \text {-value })\end{array}$ \\
\hline \multirow{3}{*}{ Stock return variance } & Family firms (1) & 3.311 & 3.628 & $\begin{array}{c}0.317^{* * *} \\
(0.008)\end{array}$ \\
\hline & Nonfamily firms (2) & 3.201 & 3.306 & $\begin{array}{l}0.105^{*} \\
(0.078)\end{array}$ \\
\hline & $(1)-(2)$ & 0.110 & 0.322 & $\begin{array}{c}0.212 * * \\
(0.030)\end{array}$ \\
\hline \multirow{3}{*}{ Trading volume } & Family firms (1) & 2.382 & 3.196 & $\begin{array}{c}0.814^{* *} \\
(0.030)\end{array}$ \\
\hline & Nonfamily firms (2) & 2.960 & 3.052 & $\begin{array}{c}0.092 \\
(0.340) \\
\end{array}$ \\
\hline & $(1)-(2)$ & -0.578 & 0.144 & $\begin{array}{l}0.722 * \\
(0.057) \\
\end{array}$ \\
\hline \multirow{3}{*}{ Bid-ask spread } & Family firms (1) & 0.236 & 0.337 & $\begin{array}{l}0.101^{* *} \\
(0.033) \\
\end{array}$ \\
\hline & Nonfamily firms (2) & 0.217 & 0.241 & $\begin{array}{c}0.024 \\
(0.209) \\
\end{array}$ \\
\hline & $(1)-(2)$ & 0.019 & 0.096 & $\begin{array}{l}0.077^{*} \\
(0.051)\end{array}$ \\
\hline
\end{tabular}


Overall, the findings in Table 8 indicate that while both family restatement firms and nonfamily restatement firms experience an increase in return variance, trading volume, and bid-ask spread following the restatement announcement, the impact is substantially more significant for family restatement firms. In fact, there is no significant difference in these three measures between nonfamily restatement firms and their matching firms up to 120 days after the restatement announcement. But for family restatement firms, the increases are still observed.

\subsubsection{Information content of earnings (ERC)}

The earnings response coefficient (ERC) is the most commonly used empirical measure of information content of earnings and a popular proxy for earnings quality (Dechow et al., 2010). A large number of studies document a significant drop in the ERC after restatement announcements (e.g., Anderson \& Yohn, 2002; Wu, 2002; Wilson, 2008; Chen et al., 2014). According to Chen et al. (2014), the key argument underlying the drop in the ERC is that the credibility of financial reporting is lower after the restatement. This argument suggests that the drop in the ERC is expected to be more severe for family restatement firms than for nonfamily restatement firms, because we argue throughout this paper that family restatement firms are subject to greater credibility concerns.

To test our prediction, we follow prior studies (e.g., Fan \& Wang, 2002; Chen et al., 2014) to estimate the following model (Equation 4):

$$
\begin{aligned}
\text { Return }_{t} & =\beta_{0}+\beta_{1} N I_{t}+\beta_{2} N I_{t} * \text { Family }_{t}+\beta_{3} N I_{t} * \text { Post } \\
& +\beta_{4} N I_{t} * \text { Post } * \text { Family }_{t}+\beta_{5} N I_{t} * \text { Firm Size }_{t} \\
& +\beta_{6} N I_{t} * \text { Tobin } Q_{t}+\beta_{7} N I_{t} * \text { Leverage }_{t}+{\text { Fixed Effects }+\varepsilon_{t}}
\end{aligned}
$$

In this model, $\operatorname{Return}_{t}$ is the cumulative net-of-market 12-month stock returns at year $t$, calculated from monthly stock returns from May to April (April 30 is the deadline for listed firms in China to release their annual reports). $N I_{t}$ is the net earnings of year $t$ divided by the 
market value of equity at the beginning of year $t$. Post is a dummy variable that indicates the post-restatement financial year. Our focus is on the coefficient $\beta_{4}$. We expect that because investors are more concerned about restatements by family firms, post-restatement earnings of family firms will be even less informative than those of nonfamily firms. Therefore, $\beta_{4}$ is expected to be negative and significant. We report the regression results in Table 9.

The tests in Table 9 include only restatement firms. The positive and significant coefficient of NI across all columns indicates that stock prices do respond to earnings in the Chinese stock markets. The insignificant coefficient of the interaction term NI*Family (coef. $=0.001, p=0.999)$ in column (1) indicates that, prior to restatements, there is no difference in the ERC between family and nonfamily firms, despite the fact that family firms are less likely to misstate their financial reports (i.e., family firms have a higher quality of earnings) as reported in Table 4.

However, the negative and significant coefficient of the interaction term $N I^{*}$ Family in column (2) (coef. $=-8.046, p=0.000$ ) indicates that after the restatement announcement, family restatement firms have a significantly lower ERC than nonfamily restatement firms. The results in column (3) confirm the finding in column (2). Although the negative coefficient of $N I^{*}$ Post (coef. $=-2.847, p=0.000$ ) indicates that nonfamily restatement firms also experience a significant drop in the ERC after restatement announcements, the drop is substantially more severe for family restatement firms, as demonstrated by the interaction term $N I^{*}$ Post $*$ Family (coef. $=-4.304, p=0.047$ ).

Overall, the findings in Table 9 confirm our prediction that the drop in the ERC after restatement announcements is more significant for family restatement firms than for nonfamily restatement firms, because family restatement firms are subject to greater credibility concerns than nonfamily restatement firms. The findings in Table 9 also provide additional support for our predictions in $H 2$ and $H 3$. 
Table 9 Family control and the effect of restatement on the information content of earnings

This table presents regression results of the effect of family control on the impact of restatement on the information content of earnings. The dependent variable is the cumulative net-of-market 12-month stock returns, calculated from monthly stock returns from May to April. Pre-restatement (columns (1)) refers to pre-restatement financial year (Year $t$-1) and post-restatement (columns (2)) refers to post-restatement financial year (Year $t+1)$, where Year $t$ refers to the year in which the restatement announcement falls. Post is a dummy variable indicating post-restatement financial year ( $t+1)$. All other variables are defined in Appendix. $P$-values based on White standard errors (White, 1980) are reported in parentheses. $*, * *$ and $* * *$ indicate significance at the $10 \%, 5 \%$ and $1 \%$ levels, respectively.

\begin{tabular}{|c|c|c|c|c|c|c|}
\hline \multirow[t]{4}{*}{ Dependent variable: } & \multicolumn{6}{|c|}{ Cumulative net-of-market 12-month stock returns (Return) } \\
\hline & \multicolumn{2}{|c|}{$(1)$} & \multicolumn{2}{|c|}{$(2)$} & \multicolumn{2}{|c|}{ (3) } \\
\hline & \multicolumn{2}{|c|}{ Pre-restatement } & \multicolumn{2}{|c|}{ Post-restatement } & \multicolumn{2}{|c|}{ Full sample period } \\
\hline & coefficient & $p$ value & coefficient & $p$ value & coefficient & $p$ value \\
\hline $\mathrm{NI}$ & $32.149 * * *$ & 0.008 & $40.580 * * *$ & 0.003 & $31.472 * * *$ & 0.000 \\
\hline $\mathrm{NI}$ Family & 0.001 & 0.999 & $-8.046 * * *$ & 0.000 & 0.068 & 0.604 \\
\hline NI*Post & & & & & $-2.847 * * *$ & 0.000 \\
\hline NI*Post*Family & & & & & $-4.304 * *$ & 0.047 \\
\hline NI*Firm size & $1.648 * * *$ & 0.004 & $1.857^{* * *}$ & 0.003 & $1.373 * * *$ & 0.004 \\
\hline $\mathrm{NI}$ *Tobin Q & $-0.996 * * *$ & 0.001 & -0.277 & 0.153 & $-0.353^{* *}$ & 0.026 \\
\hline $\mathrm{NI*Leverage}$ & $0.650 * * *$ & 0.001 & -0.018 & 0.976 & 0.428 & 0.277 \\
\hline constant & -0.086 & 0.684 & $0.619 * *$ & 0.038 & 0.334 & 0.108 \\
\hline Year effect & Included & & Included & & Included & \\
\hline Industry effect & Included & & Included & & Included & \\
\hline Obs. & 151 & & 151 & & 151 & \\
\hline Adj. R-squared & $5.03 \%$ & & $51.24 \%$ & & $23.41 \%$ & \\
\hline F-statistic & $11.99 * * *$ & & $11.32 * * *$ & & $3.91 * * *$ & \\
\hline
\end{tabular}




\section{Robustness Tests}

\subsection{Family Firms’ Greater Concern for Reputation or Alternative Explanations?}

So far in this paper, we attribute the lower rate of misstatements in family firms to the nature of family ownership, i.e., family owners' longer investment horizon and greater concern for reputation. However, it is also possible that there exist other systemic differences between family and nonfamily firms that explain the different rates of misstatements in these two groups of firms. We carry out additional tests in this section to test this possibility.

Prior studies find that a firm is less likely to misstate its financial report if it has a higher percentage of outside directors and directors with accounting or financial expertise, if the positons of CEO and the chair of the board are held by different persons, if there exists an audit committee, and the firm's external auditor is one of the Big N. In addition, the greater the number of financial analysts following the firm and the higher the frequency of board meetings, the more likely it is that accounting misstatements will be discovered and thus the lower the incentive for the management to engage in misreporting (Dechow, Sloan, \& Sweeney, 1996; Agrawal \& Chadha, 2005; Cumming, Hou, \& Lee, 2011; Firth et al., 2011; Cao et al., 2012; Kryzanowski \& Zhang, 2013).

Building on the evidence in these studies, we conduct two sets of tests. First, we test whether there are significant differences in the abovementioned characteristics between family and nonfamily firms for the whole sample that includes both restatement firms and matched firms. Second, we repeat the tests for the restatement firms only. The test results are reported in Table 10.

Columns (1) to (3) of Table 10 represent the results for the whole sample. As we can see, there is no significant difference between family and nonfamily firms in the percentage of outside directors, the number of board meetings, the percentage of firms with an audit committee, the percentage of directors with accounting or financial background, and the 
Table 10 Tests for possible alternative explanations for the lower likelihood of misstatements in family firms

This table presents the results of tests that compare several corporate governance characteristics between family and nonfamily firms. Columns (1) to (3) include the full sample that consists of both restatement firms and matched firms. Columns (4) to (6) include only restatement firms. Significances are based on $p$-values using the one-tailed t-test. ${ }^{*}, * *$ and $* * *$ indicate significance at the $10 \%, 5 \%$ and $1 \%$ levels, respectively.

\begin{tabular}{|c|c|c|c|c|c|c|}
\hline & \multicolumn{3}{|c|}{ Full sample (restatement firms \& matched firms) } & \multicolumn{3}{|c|}{ Restatement firms only } \\
\hline & $(1)$ & $(2)$ & $(3)=(1)-(2)$ & $(4)$ & $(5)$ & $(6)=(4)-(5)$ \\
\hline & Family & Nonfamily & Diff. & Family & Nonfamily & Diff. \\
\hline Outside directors & 0.362 & 0.358 & 0.004 & 0.360 & 0.359 & 0.001 \\
\hline Number of board meetings & 8.828 & 9.177 & -0.349 & 9.000 & 9.339 & -0.339 \\
\hline Audit committee & 0.494 & 0.456 & 0.038 & 0.472 & 0.461 & 0.011 \\
\hline AF background & 0.288 & 0.310 & -0.022 & 0.324 & 0.314 & 0.010 \\
\hline CEO and Chair the same person & 0.184 & 0.153 & 0.031 & 0.139 & 0.183 & -0.044 \\
\hline Big auditor & 0.299 & 0.209 & $0.090 *$ & 0.222 & 0.200 & 0.022 \\
\hline Number of financial analysts & 3.656 & 5.443 & $-1.787^{* *}$ & 2.361 & 4.983 & $-2.621 * * *$ \\
\hline Obs. & 87 & 215 & & 36 & 115 & \\
\hline
\end{tabular}


percentage of firms where the CEO and the chair are the same person. Compared to nonfamily firms, family firms are slightly more likely to hire a Big N auditor. Although a Big $\mathrm{N}$ auditor can help reduce the likelihood of an accounting misstatement, it can also indicate that family firms have greater incentive to provide higher quality financial information and therefore are more willing to hire a Big $\mathrm{N}$ auditor to help them achieve this.

We also note that compared to nonfamily firms, family firms are followed by fewer financial analysts. According to the literature, this would suggest that family firms are more likely, rather than less likely, as we find in this paper, to misstate their financial reports than nonfamily firms. Thus the results strongly support our argument that it is family owners' greater concern for reputation that deters them from misreporting.

Columns (4) to (6) represent the test results for the restatement firms only. The results again show that family restatement firms are followed by fewer financial analysts than nonfamily restatement firms. There are no significant differences between family restatement firms and nonfamily restatement firms in all other firm characteristics.

Overall, the results in Table 10 provide strong support for our argument that the lower rate of misstatements in family firms is attributable to family owners' greater concern for reputation, not systemic differences in other corporate governance characteristics.

\subsection{Alternative Definitions of Family Firms}

In this paper, a firm is defined as a family firm if it satisfies two conditions: (1) the founder and members of the founding family (either by blood or through marriage) hold at least $20 \%$ of the firm's control rights; and (2) the founding family (all family members combined) is the ultimate largest shareholder. The literature has used different definitions of family firms. In this section, we discuss several alternative definitions. 
First, studies using US data typically place no minimum, or a very low threshold, such as 5\%, for family ownership in defining family firms (e.g., Villalonga and Amit, 2006; Anderson et al., 2009). However, because the majority of non-SEOs in China have a controlling shareholder (Ma et al., 2013) this approach may be inappropriate (La Porta, Lopez-de-Silanes, \& Shleifer, 1999). Nonetheless, if we relax our definition of family firm by removing the $20 \%$ threshold for control rights, the number of family firms increases slightly from 36 to 37 in the restatement sample and from 87 to 90 in the whole sample. As the increases are minimal, we do not expect significant changes to our main findings. Robustness tests using the new samples confirm our expectation.

Second, some other studies only require one or more family members to serve as CEO, chair, or directors, with or without a significant equity ownership, for a firm to be defined as a family firm (e.g., Villalonga and Amit, 2006; Chen et al., 2008; Mehrotra, Morck, Shim, \& Wiwattanakantang, 2013).We argue that this definition may not be appropriate for the Chinese markets for two reasons. First, in countries such as US, founding families can use dual-class shares to control a substantial proportion of voting rights with a relatively small ownership. For example, the Ford family own only about 5\% of the cash flow rights of Ford Motors; yet they control $40 \%$ of the voting rights. However, dual-class shares are not permitted in China. Second, many family firms in Western countries are run by or with active involvement of the third, fourth, or even later generations of the founding family (Villalonga and Amit, 2006). The multi-generational involvement allows the founding family to insert significant influence on firm behaviour with even minimal ownership. In contrast, private ownership of a firm in China has been permitted only in the last three decades or so. As a result, the founding family can barely influence firm behaviour without a controlling ownership. For these two reasons, we believe that it is appropriate to require a $20 \%$ threshold for family ownership. 


\section{Conclusion and Implications}

Family-controlled firms are associated with some of the most high-profile accounting scandals across the world (e.g., Adelphia in the US, Parmalat in Italy, and Yin Guang Xia in China). This naturally raises two questions. Are family-controlled firms indeed more likely to have low-quality accounting information than nonfamily-controlled firms? Does family control affect investor reactions to the revelation of low quality or the deterioration of accounting information quality? These questions are important because of increasing concerns among regulators and other market participants about the widespread and increasing incidence of accounting irregularities, as well as the fact that family-controlled firms represent one of the most prevalent forms of organization across the globe. Although the first question has attracted increasing academic interest, the second question has so far been largely ignored by researchers.

In this paper, we examine the impact of family control on the likelihood of a firm misstating its financial report and on investor reactions to accounting restatements, with a focus on the latter. We find that, compared to nonfamily firms, family firms are significantly less likely to misstate their financial reports, consistent with the notion that controlling families have greater reputation concerns than nonfamily blockholders, which gives family owners a greater incentive to deliver high-quality accounting information.

We also find that following accounting restatements family-controlled firms trigger substantially stronger investor reactions, measured by more negative cumulative abnormal returns (CAR), larger abnormal return variance (ARV), larger abnormal trading volume (ATV), and higher abnormal bid-ask spread (ABAS), over a short window surrounding the restatement announcements. Further tests show that the stronger investor reactions to family firm restatements are more pronounced when the risk of expropriation by controlling 
shareholders is higher. These findings indicate that following restatement announcements investors quickly readjust their views about controlling families' concern for reputation and the risk of expropriation. Specifically, restatements lower investors' perception of the credibility of accounting information and ultimately the credibility of controlling families. In fact, the significant increases in return variance, trading volume, and bid-ask spread in family restatement firms are still observable 120 days after the restatement announcements; but these effects of restatements disappear for nonfamily restatement firms during the same period. Moreover, an examination of the ERC indicates that, after restatement announcements, investors perceive accounting earnings of family firms to be less informative than those of nonfamily firms.

Our findings have two important implications. At the firm level, this study suggests that family-controlled firms should promote a high quality of financial reporting practice with greater efforts than nonfamily-controlled firms, in order to avoid the severe penalties imposed by the market. At the policy level, to maximize the benefits of accounting information in reducing market frictions and in facilitating the development of a resilient stock market, regulators should take measures to encourage the adoption of credible reporting by all listed firms, as well as enhancing the market perception of the trustworthiness of corporate insiders by, for example, strengthening investor protection. 
Appendix A: Descriptions of key variables

\begin{tabular}{|c|c|}
\hline Variable & Description \\
\hline \multicolumn{2}{|l|}{ Dependent variables } \\
\hline Misstate & $\begin{array}{l}\text { Dummy variable that equals } 1 \text { if a firm misstates its annual financial report in a given period (and therefore has to restate the } \\
\text { financial report in a later period); zero for control firms }\end{array}$ \\
\hline Cumulative abnormal returns (CAR) & $\begin{array}{l}\text { Equals the sum of the daily abnormal returns over the event window, where daily abnormal returns are calculated using the } \\
\text { market-adjusted model. }\end{array}$ \\
\hline Abnormal return variance (ARV) & $\begin{array}{l}\text { Equals the average of the squared market-model-adjusted daily return over the event window scaled by the stock return variance } \\
\text { over the estimate window }[-120,-21] \text {. }\end{array}$ \\
\hline Abnormal trading volume (ATV) & $\begin{array}{l}\text { Equals the average of the daily trading volume over the event window scaled by the average daily trading volume over the } \\
\text { estimate window }[-120,-21] \text {. }\end{array}$ \\
\hline Abnormal bid-ask spread (ABAS) & $\begin{array}{l}\text { Equals the average of the hourly relative spread (i.e., absolute spread divided by the average of bid and ask) over the event } \\
\text { window scaled by the average of the hourly relative spread over the estimate window }[-120,-21] \text {. }\end{array}$ \\
\hline \multicolumn{2}{|l|}{ Key independent variables } \\
\hline Family & $\begin{array}{l}\text { Dummy variable that equals } 1 \text { if the ultimate largest shareholder in a firm is a family (all family member ownership combined); } \\
\text { zero otherwise }\end{array}$ \\
\hline Post & Dummy variable indicating post-restatement period \\
\hline Ownership wedge & The difference between control rights and cash flow rights of the ultimate largest shareholder \\
\hline Corporate opacity & $\begin{array}{l}\text { An index that ranks four components, trading volume, analyst coverage, zero-return trading days, and stock return volatility in } \\
\text { deciles and divides the sum of the four components by } 40 \text {, resulting in an opacity index between } 0 \text { and } 1 \text {. A higher value of opacity } \\
\text { index indicates that a firm's information is more opaque. }\end{array}$ \\
\hline \multicolumn{2}{|r|}{ e } \\
\hline Firm size & Natural log of total assets \\
\hline Leverage & Total liabilities / total assets \\
\hline ROA & Net income / total assets \\
\hline Top share & The proportion of equity ownership by the largest shareholder \\
\hline Outside directors & Number of independent directors / total number of directors \\
\hline Big auditor & Dummy variable that equals 1 if a firm's annual report is audited by one of the largest 10 auditing firms in China; zero otherwise \\
\hline MAO & Dummy variable that equals 1 if a firm receives a modified (qualified) audit opinion on its annual report; zero otherwise \\
\hline Negative EPS & Dummy variable that equals 1 if a firm has a negative EPS (earnings per share); zero otherwise \\
\hline Reform & Dummy variable that equals 1 if a firm has completed the nontradable share reform; zero otherwise \\
\hline Audit committee & Dummy variable that equals 1 if there exists an audit committee within the firm \\
\hline AF Background & The ratio of board members who have either accounting or financial background \\
\hline
\end{tabular}




\section{Appendix B Examples of accounting errors and irregularities}

This list is not meant to be an exhaustive list of all types of accounting errors and irregularities that have occurred in China. Rather, the examples listed here indicate how we classify various accounting restatements into accounting errors and irregularities.

Panel A: Examples of accounting errors

\begin{tabular}{|c|c|c|c|}
\hline Stock code & $\begin{array}{l}\text { Announcement date } \\
\text { (YYYY/MM/DD) }\end{array}$ & Reasons for restatement / before restatement & Actions taken / after restatement \\
\hline 000062 & $2010 / 04 / 09$ & $\begin{array}{l}\text { A joint-partner company was mistakenly shown in the annual report as } \\
\text { a subsidiary }\end{array}$ & The restatement corrected this mistake \\
\hline 000150 & $2009 / 04 / 30$ & $\begin{array}{l}\text { This company would purchase Mr. Wang's } 4 \% \text { ownership in this } \\
\text { company for a price of ' } 7,200,574.25 \text { wan yuan' }\end{array}$ & ...for a price of ' $7,200,574.25$ yuan' \\
\hline 000662 & $2009 / 04 / 11$ & The number of shareholders was 22,917 & The number was changed to 31,891 \\
\hline 000683 & $2009 / 04 / 10$ & $\begin{array}{l}\text { Discrepancies between figures in Cash Flow Statement and those in } \\
\text { Notes to the Statement. The figures in the Statement were incorrect }\end{array}$ & $\begin{array}{l}\text { Cash inflows in relation to operations was changed from } \\
1,121,868,936 \text { yuan to } 721,868,936 \text { yuan; Cash outflows } \\
\text { in relation to operations was changed from } 888,410,372 \\
\text { yuan to } 488,410,372 \text { yuan }\end{array}$ \\
\hline 000939 & $2009 / 05 / 16$ & $\begin{array}{l}\text { 1) owners' equity was shown in the annual report as } 36884 \text { wan yuan; } \\
\text { 2) the figures in page } 58 \text { of the annual report were in the unit of yuan; } \\
\text { 3) an nonexistent related party transaction was mistakenly shown in } \\
\text { the report }\end{array}$ & $\begin{array}{l}\text { 1) Owners' equity was changed to } 36848 \text { wan yuan; } 2) \\
\text { those figures were changed to in the unit of wan yuan; } 3 \text { ) } \\
\text { this transaction was removed }\end{array}$ \\
\hline 002081 & $2008 / 03 / 31$ & $\begin{array}{l}\text { In the list of top } 10 \text { unrestricted largest shareholders, the names of the } \\
\text { number } 9 \text { and } 10 \text { shareholders were incorrect }\end{array}$ & The restatement corrected this mistake \\
\hline 002139 & $2008 / 03 / 29$ & $\begin{array}{l}\text { In Note } 11 \text { to the financial report, next to the compensation of three } \\
\text { directors, there was a remark which said "independent direct } \\
\text { allowance" }\end{array}$ & The restatement removed this remark. \\
\hline 600331 & $2006 / 03 / 22$ & $\begin{array}{l}\text { Due to miscalculation, the increase in fixed assets was reported as } \\
752,018,731 \text { yuan and accumulated depreciation was reported as } \\
96,518,807 \text { yuan }\end{array}$ & $\begin{array}{l}\text { The restatement changed these two figures to } \\
756,677,479 \text { yuan and } 96,883,862 \text { yuan, respectively. }\end{array}$ \\
\hline 600366 & $2007 / 05 / 15$ & $\begin{array}{l}\text { The term of an independent director, Mr. Qian Weishen, expired on } \\
2009 / 04 / 27\end{array}$ & ...expired on $2007 / 04 / 25$ \\
\hline 600481 & $2006 / 04 / 11$ & $\begin{array}{l}\text { 1) Total compensation of directors, supervisors, and senior executives } \\
\text { was } 186 \text { wan yuan; } 2 \text { ) total amount of related party transections with } \\
\text { controlling shareholders and subsidiaries was } 382 \text { yuan }\end{array}$ & $\begin{array}{l}\text { After correction, total compensation was } 206 \text { wan yuan; } \\
\text { total related party transactions were } 382 \text { wan yuan }\end{array}$ \\
\hline
\end{tabular}


Panel B: Examples of accounting irregularities

\begin{tabular}{|c|c|c|c|}
\hline Stock code & $\begin{array}{l}\text { Announcement date } \\
\text { (YYYY/MM/DD) }\end{array}$ & Reasons for restatement / before restatement & Actions taken / after restatement \\
\hline 000078 & $2009 / 04 / 27$ & $\begin{array}{l}\text { An sale of assets was not completed but income had been } \\
\text { recorded in the financial report }\end{array}$ & Net profit and equity were reduced by $18,650,860$ yuan \\
\hline 000509 & $2006 / 03 / 18$ & $\begin{array}{l}\text { 1) Incomes in previous years were artificially inflated; 2) bad } \\
\text { debt reserves were underestimated }\end{array}$ & Retained earnings was reduced by $54,900,261$ yuan \\
\hline 000558 & $2006 / 02 / 16$ & $\begin{array}{l}\text { Tax payable and tax expense in one subsidiary was } \\
\text { underestimated }\end{array}$ & Profit and retained earnings were reduced by $1,145,010$ yuan \\
\hline 000760 & $2007 / 03 / 22$ & Some expenses were not reported & Retained earnings in 2005 was reduced by $4,225,726$ yuan \\
\hline 000998 & $2009 / 06 / 29$ & $\begin{array}{l}\text { Gain from the sale of part equity was recorded as the profit } \\
\text { in } 2008 \text {. However, the regulator required it not be } \\
\text { recognised as profit }\end{array}$ & $\begin{array}{l}\text { Total assets in } 2008 \text { was reduced by } 24,924,930 \text { yuan; net profit was } \\
\text { reduced by } 24,844,394 \text { yuan; EPS was reduced by } 0.083 \text { yuan }\end{array}$ \\
\hline 600311 & $2006 / 04 / 26$ & $\begin{array}{l}\text { 1) Some Short-term bank loans were not reported; 2) } \\
\text { associated financial expenses were not recognised }\end{array}$ & $\begin{array}{l}\text { 1) Short-term loans were increased by } 70,000,000 \text { yuan; } 2 \text { ) financial } \\
\text { expenses were increased by } 3,596,647 \text { yuan; } 3 \text { )net profit was } \\
\text { reduced by } 12,004,613 \text { yuan }\end{array}$ \\
\hline 600711 & $2004 / 02 / 14$ & $\begin{array}{l}\text { 1) Incorrectly treated long-term equity investment; } 2 \text { ) did not } \\
\text { disclose loan guarantee provided for its whole owned } \\
\text { subsidiaries }\end{array}$ & $\begin{array}{l}\text { 1) Long-term equity investment was reduced by } 2,309,763 \text { yuan; } 2 \text { ) } \\
\text { disclosed that the listed company had provided loan guarantee of } \\
48,5000,000 \text { yuan }\end{array}$ \\
\hline 600840 & $2005 / 03 / 12$ & Accrual of tax payable was underestimated & Retained earnings was reduced by $3,275,563$ yuan \\
\hline 600873 & $2009 / 10 / 27$ & $\begin{array}{l}\text { An ongoing litigation, which if won could potentially have } \\
\text { positive impact on earnings, is unlikely to have the expected } \\
\text { outcome because the defendant had gone missing }\end{array}$ & $\begin{array}{l}\text { Retained earnings and owners' equity in } 2007 \text { and } 2008 \text { were } \\
\text { reduced by } 1,860,354 \text { yuan and 2,547,106 yuan, respectively }\end{array}$ \\
\hline
\end{tabular}




\section{References:}

Agrawal, A., and S. Chadha, 2005, Corporate governance and accounting scandals, Journal of Law and Economics, 48, 371-406.

Allen, F., J. Qian, and M. Qian, 2005, Law, finance, and economic growth in China. Journal of Financial Economics, 77, 57-116.

Anderson, K. L., and T. L. Yohn, 2002, The effect of 10-K restatements on firm value, information asymmetries, and investors' reliance on earnings. Unpublished manuscript. Georgetown University.

Anderson, R., A. Duru, and D. Reeb, 2009, Founders, heirs, and corporate opacity in the United States. Journal of Financial Economics, 92, 205-222.

Armstrong, C. S., W. R. Guay, and J. P. Weber, 2010, The role of information and financial reporting in corporate governance and debt contracting. Journal of Accounting and Economics, 50, 179-234.

Burgoon, J. K., and B. A. LePoire, 1993, Effects of communication expectancies, actual communication, and expectancy disconfirmation on evaluations of communicators and their communication behavior. Human Communication Research, 20, 67-96.

Burkart, M., F. Panunzi, and A. Shleifer, 2003, Family firms. Journal of Finance, 58, 2167-2202.

Bushman, R. M., and A. Smith, 2001, Financial accounting information and corporate governance. Journal of Accounting and Economics, 32, 237-351.

Cai, J. 2004, Bid-ask spreads for trading Chinese stocks listed on domestic and international exchanges. Unpublished manuscript, Shanghai Stock Exchange.

Callen, J., S. Robb, and D. Segal, 2008, Revenue manipulation and restatements by loss firms. Auditing: A Journal of Practice and Theory, 27, 1-29.

Cao, Y., L. Myers, and T. Omer, 2012, Does company reputation matter for financial reporting quality? Evidence from restatements. Contemporary Accounting Research, 29, 956-990.

Cascino, S., A. Pugliese, D. Mussolino, and C. Sansone, 2010, The influence of family ownership on the quality of accounting information. Family Business Review, 23, 246-265.

Chen, T. 2005, Executive compensation contracts of family firms. Unpublished manuscript. University of Texas at Dallas.

Chen, H., J. Z. Chen, G. J. Lobo, and Y. Wang, 2011, Effects of audit quality on earnings management and cost of equity capital: Evidence from China. Contemporary Accounting Research, 28, 892-925. 
Chen, S., X. Chen, and Q. Cheng, 2008, Do family firms provide more or less voluntary disclosure? Journal of Accounting Research, 46, 499-536.

Chen, S., X. Chen, and Q. Cheng, 2014. Conservatism and equity ownership of the founding family. European Accounting Review, 23, 403-430.

Chen, X., Q. Cheng, and A. K. Lo, 2014, Is the decline in the information content of earnings following restatements short-lived? The Accounting Review, 89, 177-207.

Chen, J., D. Cumming, W. Hou, and E. Lee, 2013, Executive integrity, audit opinion, and fraud in Chinese listed firms. Emerging Markets Review, 15, 72-91.

Claessens, S., S. Djankov, J. P. H. Fan, and L. H. P. Lang, 2002, Disentangling the incentive and entrenchment effects of large shareholdings. Journal of Finance, 57, 2741-2772.

Coffee, Jr., J. C. 2005, A theory of corporate scandals: Why the USA and Europe differ. Oxford Review of Economic Policy, 21, 198-211.

Cumming, D., W. Hou, and E. Lee, 2011, The role of financial analysts in deterring corporate fraud in China. Working paper, SSRN, Accessed Feb. 1, 2016.

Dechow, P., R. Sloan, and A. Sweeney, 1996, Causes and Consequences of earnings manipulation: An analysis of firms subject to enforcement actions by the SEC. Contemporary Accounting Research, 13, 1-36.

Dechow, P., W. Ge, and C. Schrand, 2010, Understanding earnings quality: A review of the proxies, their determinants and their consequences. Journal of Accounting and Economics, 50, 344-401.

DeFond, M., and J. Jiambalvo, 1991, Incidence and circumstances of accounting errors. The Accounting Review, $66,643-55$.

DeFond, M., M. Hung, and R. Trezevant, 2007, Investor protection and the information content of annual earnings announcements: International evidence. Journal of Accounting and Economics, 43, 37-67.

Dyck, A., and L. Zingales, 2003, The media and asset prices. Unpublished manuscript. Harvard University.

Dyck, A., and L. Zingales, 2004, Private benefits of control: An international comparison. Journal of Finance, 59, 537-600.

Faber, D. B. 2005, Restoring trust after fraud: Does corporate governance matter? The Accounting Review, 80, 539-561.

Fan, J. P. H., and T. J. Wong, 2002, Corporate ownership structure and the informativeness of accounting earnings in East Asia. Journal of Accounting and Finance, 33, 401-425. 
Fan, J. P. H., T. J. Wong, and T. Zhang, 2012, Founder succession and accounting properties. Contemporary Accounting Research, 29, 283-311.

Firth, M., O. Rui, and W. Wu, 2011, Cooking the books: Recipes and costs of falsified financial statements in China. Journal of Corporate Finance, 17, 371-390.

Fombrun, C., and M. Shanley, 1990, What's in a name? Reputation building and corporate strategy. Academy of Management Journal, 33, 233-258.

Friedman, M. 1969, The optimum quantity of money. Aldine Publishing Co.: Chicago.

Gilson, R. J. 2007, Controlling family shareholders in developing countries: Anchoring relational exchange. Stanford Law Review, 60, 633-655.

Graham, J., S. Li, and J. Qiu, 2008, Corporate misreporting and bank loan contracting. Journal of Financial Economics, 89, 44-61.

Healy, P. M., and K. G. Palepu, 2001, Information asymmetry, corporate disclosure, and the capital markets: A review of the empirical disclosure literature. Journal of Accounting and Economics, 31, 405-440.

Hennes, K., A. Leone, and B. Miller, 2008, The importance of distinguishing errors from irregularities in restatement research: The case of restatements and CEO/CFO turnover. The Accounting Review, 83, 14871519.

Hoffman, A. J., and W. Ocasio, 2001, Not all events are attended equally: Toward a middle-range theory of industry attention to external events. Organization Science, 12, 414-434.

Hribar, P., and N. T. Jenkins, 2004, The effect of accounting restatements on earnings revisions and the estimated cost of capital. Review of Accounting Studies, 9, 337-356.

Jensen, M., and W. Meckling, 1976, Theory of the firm: Managerial behavior, agency costs and ownership structure. Journal of Financial Economics, 3, 305-360.

Karpoff, J. M. 1987, The relation between price changes and trading volume: A survey. Journal of Financial and quantitative Analysis, 22, 109-126.

Karpoff, J., S. Lee, and G. Martin, 2008, The cost to firms of cooking the books. Journal of Financial and Quantitative Analysis, 43, 581-612.

Kinney, W. Jr., and L. McDaniel, 1989, Characteristics of firms correcting previously reported quarterly earnings. Journal of Accounting and Economics, 11, 71-93.

Kouwenberg, R., and V. Phunnarungsi, 2013, Corporate governance, violations and market reactions. PacificBasin Finance Journal, 21, 881-898. 
Kryzanowski, L., and Y. Zhang, 2013, Financial restatements and Sarbanes-Oxley: Impact on Canadian firm governance and management turnover. Journal of Corporate Finance, 21, 87-105.

La Porta, R., F. Lopez-de-Silanes, and A. Shleifer, 1999, Corporate ownership around the world. Journal of Finance, 54, 471-517.

Lei, M., W. F. Wu, C. F. Wu, and M. Rui, 2006, Financial restatements of listed companies in China. Shanghai Management Science (in Chinese), 4, 38-43.

Leone, A., and M. Liu, 2010, Accounting irregularities and executive turnover in founder-manager firms. The Accounting Review, 85, 287-314.

Leuz, C., D. Nanda, and P. Wysocki, 2003, Earnings management and investor protection: An international comparison. Journal of Financial Economics, 69, 505-527.

Ma, L., S. Ma, and G. Tian, 2013, Political connections, founder-managers, and their impact on tunneling in China’s listed firms. Pacific-Basin Finance Journal, 24, 312-339.

Ma, L., S. Ma, and G. Tian, 2015, Corporate opacity and cost of debt for family firms. European Accounting Review, Forthcoming, DOI: 10.1080/09638180.2015.1087868.

MacNeil, I. 2002, Adaptation and convergence in corporate governance: the case of Chinese listed companies. Journal of Corporate Law Studies, 2, 289-344.

Mehrotra, V., R. Morck, J. Shim, and Y. Wiwattanakantang, 2013, Adoptive expectations: Rising sons in Japanese family firms. Journal of Financial Economics, 108, 840-854.

Miller, D., I. Le Breton-Miller, and B. Scholnick, 2008, Stewardship vs. stagnation: An empirical comparison of small family and non-family businesses. Journal of Management Studies, 45, 51-78.

Miller, G. S. 2006, The press as a watchdog for accounting fraud. Journal of Accounting Research, 44, 10011033.

Murphy, D. L., R. E. Shrieves, and S. L. Tibbs, 2009, Understanding the penalties associated with corporate misconduct: An empirical examination of earnings and risk. Journal of Financial and Quantitative Analysis, 44, 55-83.

Palmrose, Z., and S. Scholz, 2004, The circumstances and legal consequences of non-GAAP reporting: Evidence from restatements. Contemporary Accounting Research, 21, 139-180.

Palmrose, Z., V. Richardson, and S. Scholz, 2004, Determinants of market reactions to restatement announcements. Journal of Accounting and Economics, 37, 59-89. 
Peterson, K. 2012, Accounting complexity, misreporting, and the consequences of misreporting. Review of Accounting Studies, 17, 72-95.

Pevzner, M., F. Xie, and X. Xin, 2015. When firms talk, do investors listen? The role of trust in stock market reactions to corporate earnings announcements. Journal of Financial Economics. 117, 190-223.

Rhee, M., and P. R. Haunschild, 2006, The liability of good reputation: A study of product recalls in the U.S. automobile industry. Organization Science, 17, 101-117.

Schulze, W. S., M. H. Lubatkin, and R. N. Dino, 2003, Toward a theory of agency and altruism in family firms. Journal of Business Venturing, 18, 473-490.

Shleifer, A., and R. Vishny, 1997, A survey of corporate governance. Journal of Finance, 52, 737-783.

Srinivasan, S., A. S. Wahid, and G. Yu, 2015, Admitting mistakes: Home country effect on the reliability of restatement reporting. The Accounting Review, 90, 1201-1240.

Teoh, S. H., and T. J. Wong, 1993, Perceived auditor quality and the earnings response coefficient. The Accounting Review, 68, 346-366.

Tong, Y. H., 2007, Financial reporting practices of family firms. Advances in Accounting, 23, 231-261.

Villalonga, B., and R., Amit, 2006, How do family ownership, control and management affect firm value? Journal of Financial Economics, 80, 385-417.

Wang, D. 2006, Founding family ownership and earnings quality. Journal of Accounting Research, 44, 619-656.

Wilson, W. M. 2008, An empirical analysis of the decline in the information content of earnings following restatements. The Accounting Review, 83, 519-548.

Wu, M. 2002, Earnings restatements: A capital market perspective. Unpublished manuscript. New York University. 